\title{
Assessment of the Facial Harmony Among Spaniards of White Ethnicity Aged 18 to 60 Years Old and its Relationship With the Golden Ratio
}

"The beautiful is that which pleases universally without a concept" Immanuel Kant

\section{Introduction}

Can we define the parameters of facial beauty? That would be the question underlying this study.

What is considered beautiful has changed through history, influenced by fashion trends, interests or needs.

In Ancient History, beauty was a synonym of fertility and nutritional reserves, as we can appreciate in the sculpture "Venus of Willendorf" (approx. 25.000 B.C.) (fig. 1), in which the genitals are perfectly detailed and the fat reserve make the hip reach the same size as the total height of the statue. However, it does not have a face.

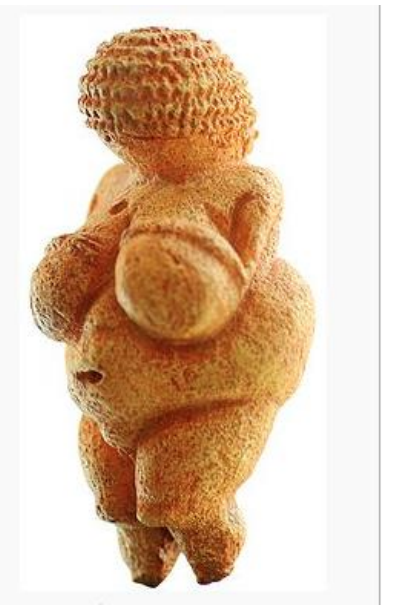

Figure 1

In Ancient Egypt, the need to represent divinities as well as the abundance of alimentary resources leads to the development of the first aesthetic canon (Fig. 2) and today a constant remains: sexuality linked to reproduction. Beautiful women were those who, besides abiding by the canon, had wide hips (Fig. 3). 

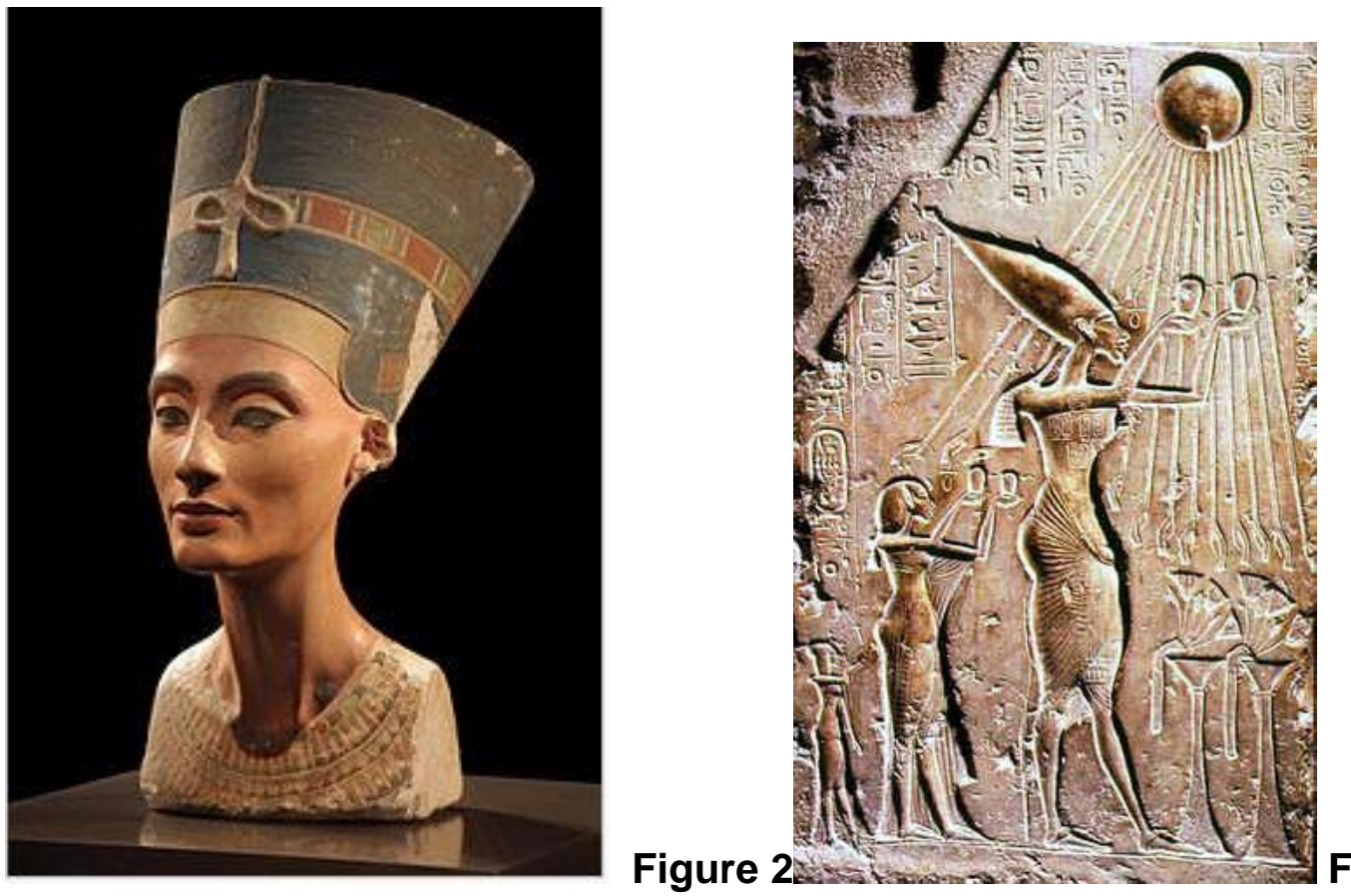

3

Figure

The notion of beauty is intimately linked to the Maslow pyramid (1943) (1) (Fig. 4 ) and to the characteristics of the universe: symmetry and proportion (Phi number $=1.618$ ).

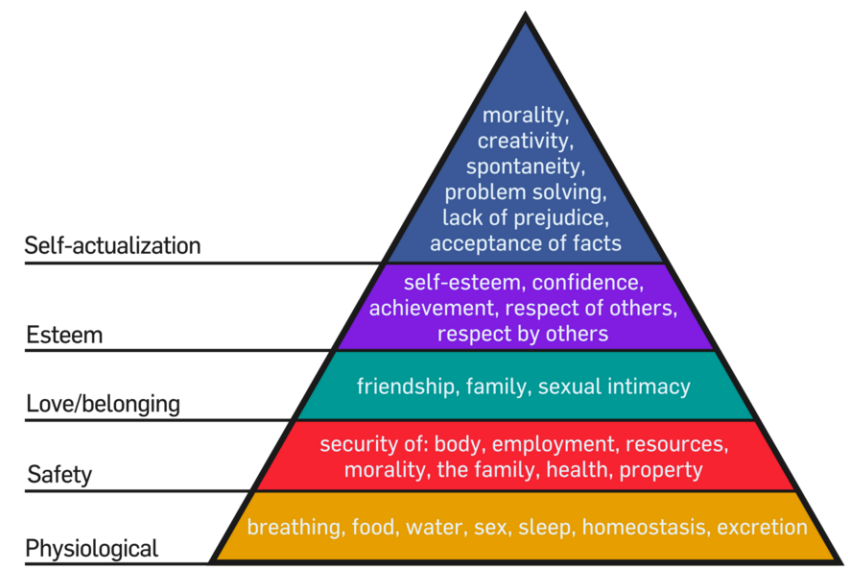

\section{Figure 4}

Beauty has thus a place among our "needs". There is a subjective component in its appreciation by the individual moulded by the cultural system in which he finds himself, by the survival needs and by the aesthetic tastes of his lifetime.

Accepting that there is a subjective component to it, are there also objective, quantifiable and measurable parameters in that which we consider beautiful?

Measuring beauty, understanding it and framing it have been a constant throughout human history.

There have been many beauty canons in different civilisations, and very different from each other, however an attempt to establish a universal law comes with the Divine Proportion, which is found in nature, artistic creations, design and of 
course the human body itself.

But what is the Divine Proportion and what relationship does it hold with beauty?

It's defined by the Golden Ratio ( $\left.\phi=\frac{1+\sqrt{5}}{2}=1,6180339 \ldots\right)$ (Fig. 5), an irrational number used since the antiquity. It stems from the division of a segment in two keeping the following proportions:

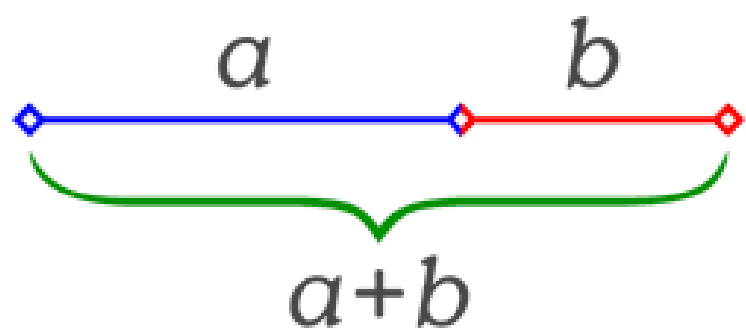

Figure 5: The Divine Proportion. The total length, "a+b", is to the longest section "a" what "a" is to the shortest section, "b".

In ancient Greece, Plato (427-347 BC) related beauty with kindness, which were synonyms to him. The subtitle of his book "The banquet", where beauty is widely discussed, states "About the good".

Even if Aristotle (384-322 BC) already related the concept of beauty to proportion and symmetry by linking art with mathematics, the first one to carry out a study on the Golden Ratio was Euclid (325-265 BC) in "The Elements", definition 3 of the sixth book.

In the Middle Ages (St. Thomas Aquinas, 1225-1274 A.D.), Christianity dominates every aspect of life in the Western world, and hence the concept of beauty is overruled by divine intervention.

In "Human Figure" (1489), Leonardo da Vinci pictures anatomic drawings not only as art, but also as a scientific observation, showing deformed faces to illustrate the "grotesque" and the changes that the elderly or deformed people underwent (Fig. 7 and 8). When we look for beauty on a face we assume we talk about a young face. 


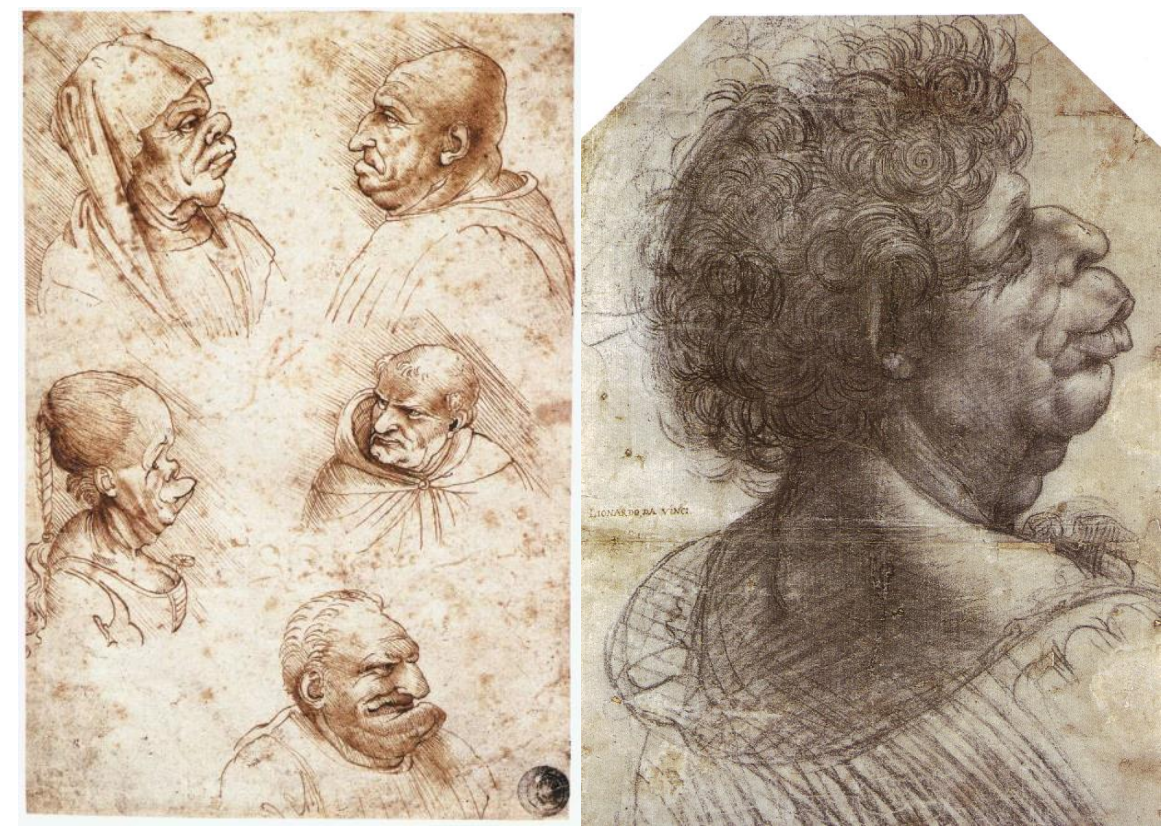

Figures 6 y 7: Studies on "grotesque" faces, Leonardo da Vinci

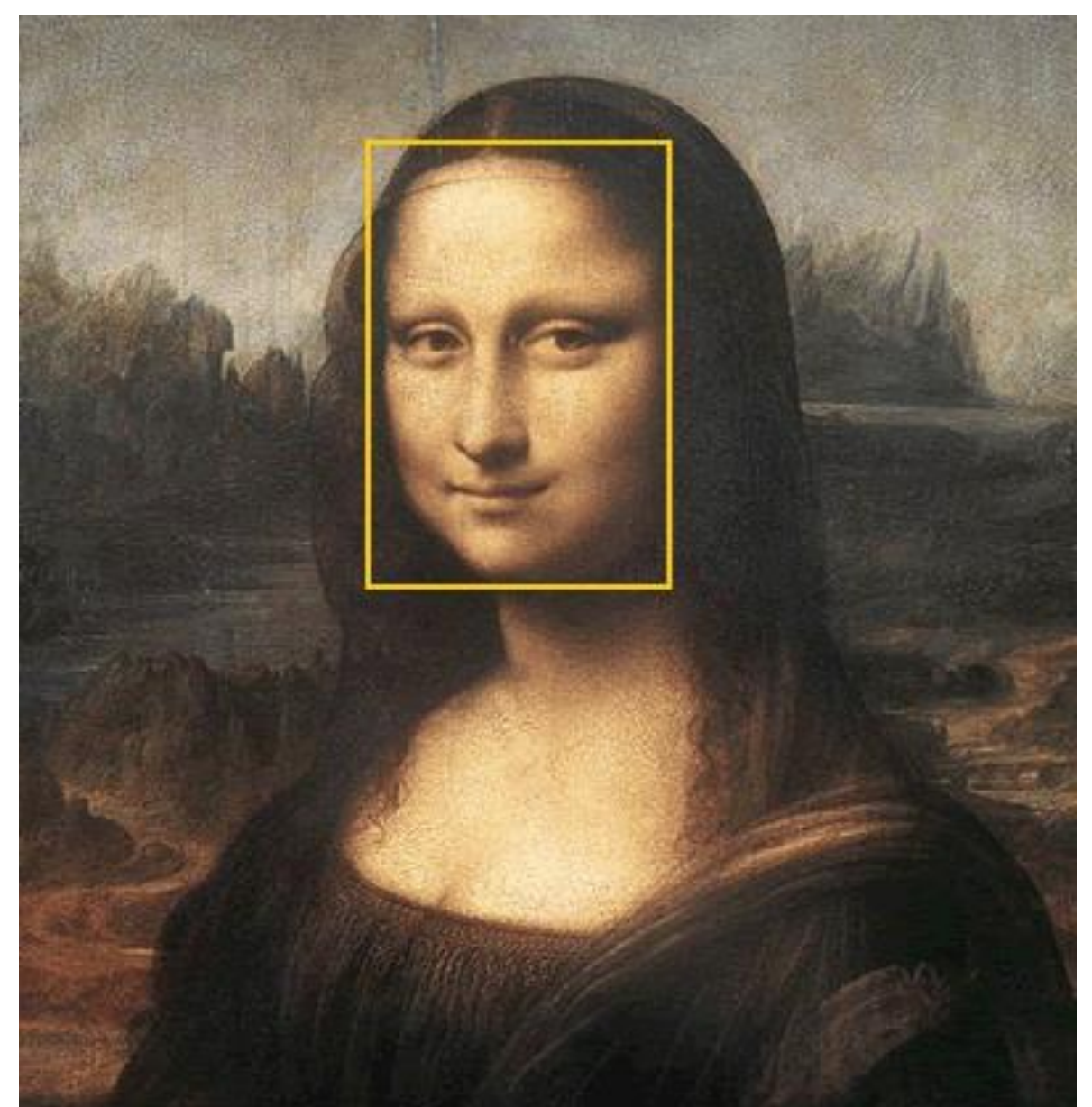

Figure 8: The Mona Lisa, Leonardo da Vinci. The face has the proportions of a rectangle based on the Golden Ratio.

The economic growth in Venice and Florence develops the new beauty canon of the Renaissance. In "Vitruvian Man" (fig. 4), dated 1489, Leonardo da Vinci conceives anatomic drawings not only as art, but also as scientific observation. 


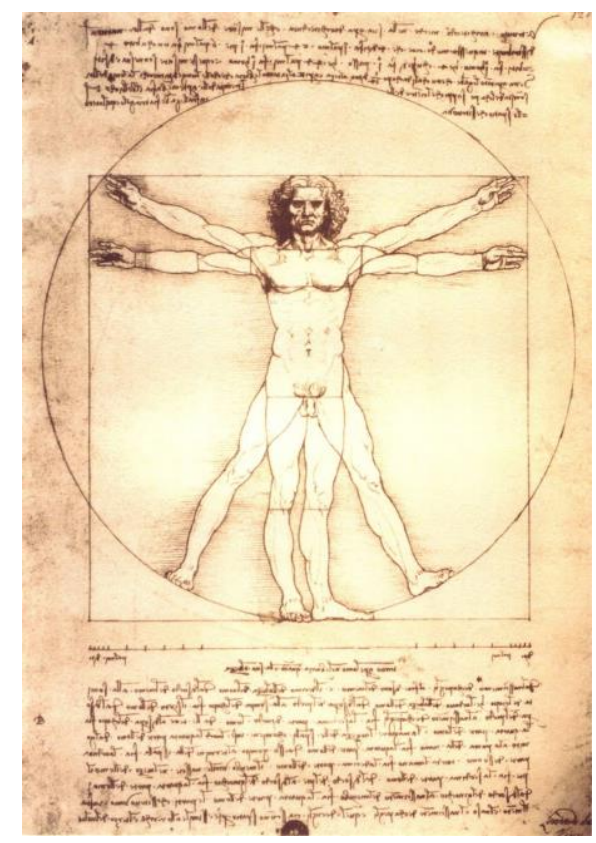

\section{Figure 9}

Before the Industrial Revolution, clothing was Taylor-fitted. During the XIXth century, clothing begins to become standard with some proportions, excluding people that weren't physically adapted to them.

From then on, the individual is the one that starts adapting to clothing and not the other way around, looking for that beauty ideal, or better said, looking to be included in that "normal" group and not being classified as "ugly".

This mentality has kept going until nowadays, with the beauty canons being diffused globally through mass media and increasing "ugly" people's exclusion and social anxiety.

In our society, media create a wish to emulate the model, not only by making people want to acquire its accessories (purses, watches, jewellery, shoes etc.) but also making them want their physical traits (nose, smile, eyes, body etc.). Hönn (2007)(18) discovered how the beauty ideals are subject to certain fluctuations depending on fashion trends.

Even if the concept of "beauty" changes along history, it remains almost constant throughout several generations, which is why we can consider it a cultural phenomenon Fusshan, Farkas L.G, (2005) (1), Germec-Cakan, (2010) and depending on the ethnicity Jefferson, (1993) (23). 


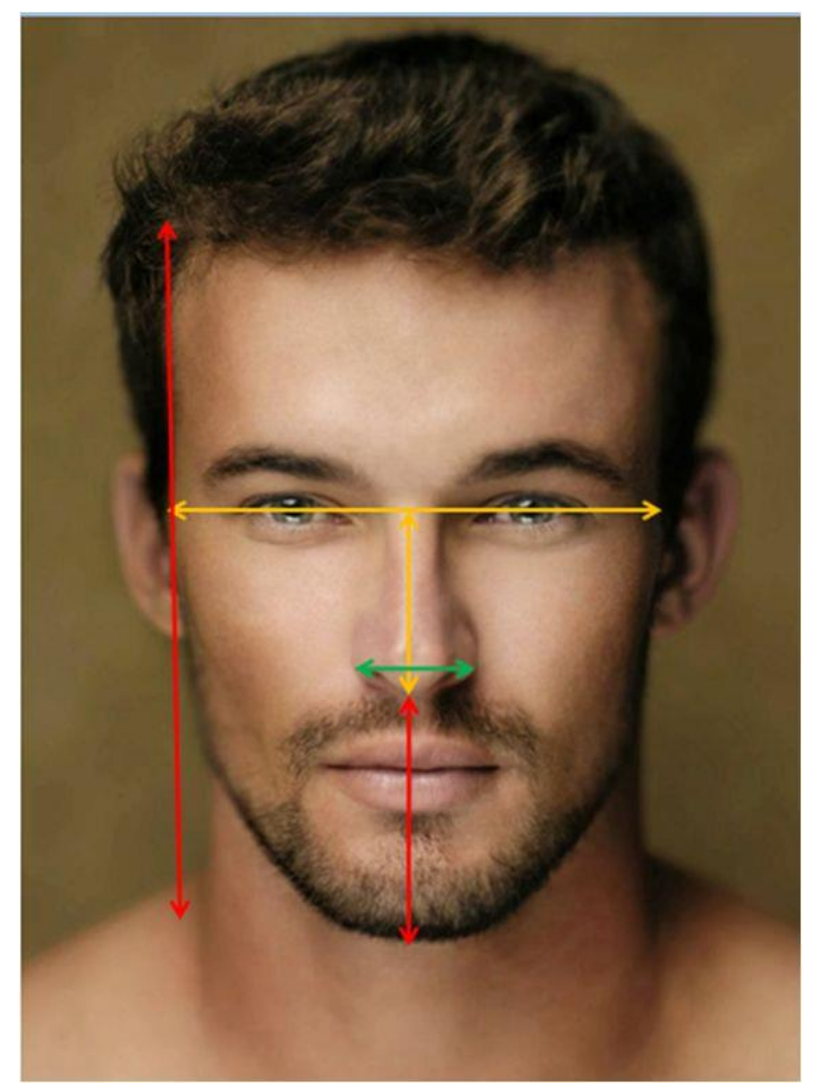

Figure 10: Divine Proportion on a face

The reiterated use of this proportion in the world of art and its relationship with beauty beyond temporary trends encourages to study this concept deeper, regardless of the intentional or intuitive use of the Golden Ratio.

The purpose of this article is to determine if a "beauty norm" is accepted in our culture and if it is, whether it has a relationship with the Golden Ratio, as stated by Ricketts (1982)(2), Preston (1993)(3) and Amoric (1995)(13) or if, on the contrary, this Golden Ratio shouldn't be a reference in the search for the "attractive". Baker and Woods (2001)(13)), Shell and Woods (2004)(11), Holland (2008)(5)(2008), Rossetti (2013)(29), Rajiv and Juhi (2014)(10).

\section{Materials and Methodology}

\section{II. a. Objectives.}

Main Objective: to determine if there is a beauty "normality" widely accepted by our society and if it has any relationship with the Golden Ratio.

Secondary Objectives: In case there is a positive answer to the issue stated above, to determine the intervals of "normality" in the different Golden Ratios and find out what kind of nose, smile, jaw, chin and 
maxillary are considered the "normality" of beauty.

\section{II. b. Survey.}

\section{1.- Method Design and Population of the Study.}

Prospective study, not randomised, realised between September 2015 and December 2015 structured in 5 phases:

\section{a.- Question creation.}

A questionnaire (Annex 1) comprising all the elements relevant to facial aesthetics (front, profile, nose, cheekbones, eyes, lips, chin, smile) was made according to the VASS (Visual Analog Scale Score) protocol.

The questionnaire was made of 3 parts. A first one with 15 questions where the models are analysed in a front view, a second one with 14 questions about side-faced models and a third one with 5 questions where the suitability of surgical interventions is assessed.

On each part, the questions have a Likert-type answer with 5 categories, whereby 1 means "very good looking" and 5 "very ugly" and other questions where a visual scale is used with 0 as "very ugly" and 10 as "very good looking".

\section{b.- Election of the analysed pictures.}

The studied images were taken from advertising models, fashion magazines, acting roles etc. exclusively from white ethnicity and appearing commonly in "gossip magazines" and that are between 18 and 60 years old. The total number of models studied was 9 .

\section{c.- Data Collection.}

54 people replied, of which 50 filed out the 9 questionnaires, 1 filled out 8 of them and 3 people filled out 6 of them. In total, 466 questionnaires, which means 13,514 questions answered by people picked at random (without consideration of their educational background), representing both sexes on a 5050 basis and aged between 18 and 60 years old.

\section{d.- Data Processing.}

A database was prepared on an Excel spreadsheet from the data collected in the survey and it was then exported to the statistics package R.3.2 for Windows to carry out its analysis afterwards.

\section{e.- Statistical Analysis.}


Frequencies and percentages of qualitative variables and means and standard deviations of quantitative variables were calculated.

In order to study the relationship between qualitative ordinal variables, we used the Kendall coefficient of correlation, based on the Kendall Tau coefficient, normally used in the analysis of concordance for attributes.

In order to analyse if there is any relationship between quantitative variables, the Pearson correlation coefficient was calculated between both variables and as a dimension reduction technique, the use of an analysis of main components was considered.

\section{E.1. Analysis of the Survey on Facial Harmony, Balance, Beauty and Normality: Results}

I. Study of the facial harmony and balance $(1,2,13,14,15,16,17,28,29)$

Question no 1. General Appearance (table 1 and 2)

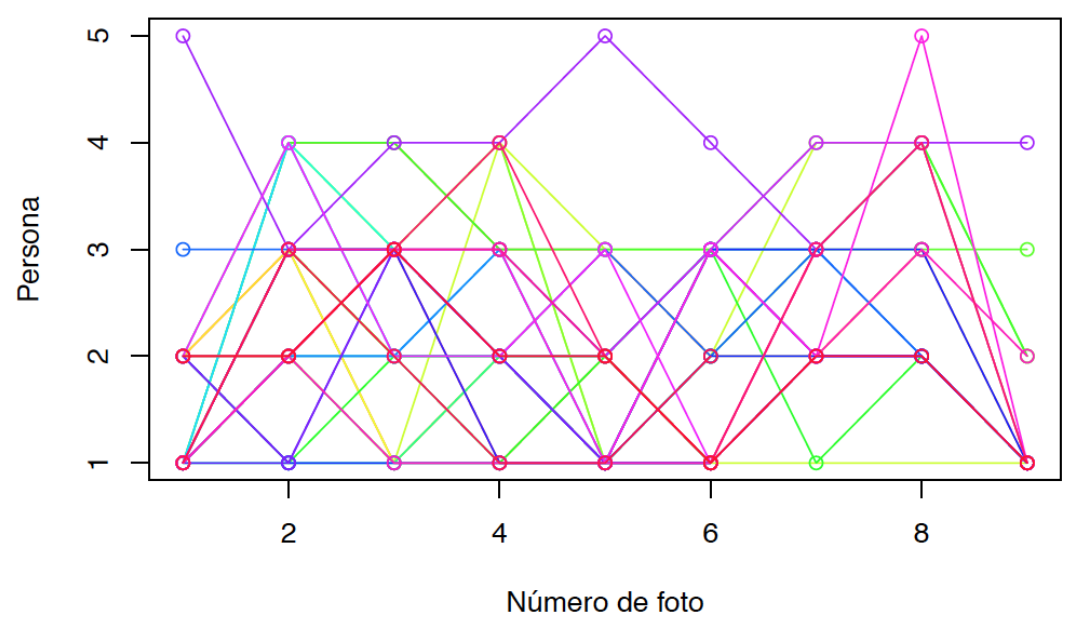

Table 1

If we put together the answers "very good looking", "good looking" and "normal" (those where an orthognathic surgical intervention wouldn't be justified in any case) under the label "normality"(1) and then we keep the labels "ugly" (2) and "very ugly" (3), the distribution of the scores awarded to the pictures is as follows:

\begin{tabular}{|c|c|c|c|c|c|c|c|c|c|c|}
\hline & \multicolumn{10}{|c|}{ Picture $\mathrm{n}^{-}$} \\
\hline Score & 1 & 2 & 3 & 4 & 5 & 6 & 7 & 8 & 9 & Total \\
\hline 1 & 53 & 45 & 51 & 47 & 53 & 51 & 31 & 20 & 31 & $382(90.09 \%)$ \\
\hline 2 & 0 & 9 & 3 & 7 & 0 & 2 & 5 & 12 & 1 & $39(9.2 \%)$ \\
\hline 3 & 1 & 0 & 0 & 0 & 1 & 0 & 0 & 1 & 0 & $3(0.71 \%)$ \\
\hline Total & 54 & 54 & 54 & 54 & 54 & 53 & 36 & 33 & 32 & \\
\hline
\end{tabular}




\section{Table 2}

Which shows $90.09 \%$ of "normality", $9.2 \%$ "ugly" and $0.71 \%$ "very ugly".

The top percentages of "normality" are reached for pictures 1 and 3 with a result of $98.15 \%$ and the worst result is the one obtained by number 8 , with only $63.64 \%$.

Question no 2. Facial harmony and balance (table 3)

Questions 2 and 17 assess harmony and balance of the face (front view and sideways respectively). When comparing their answers we obtain a "Kendall's Rank Correlation Tau" of 0.635 , which is why we can conclude that they are closely correlated.

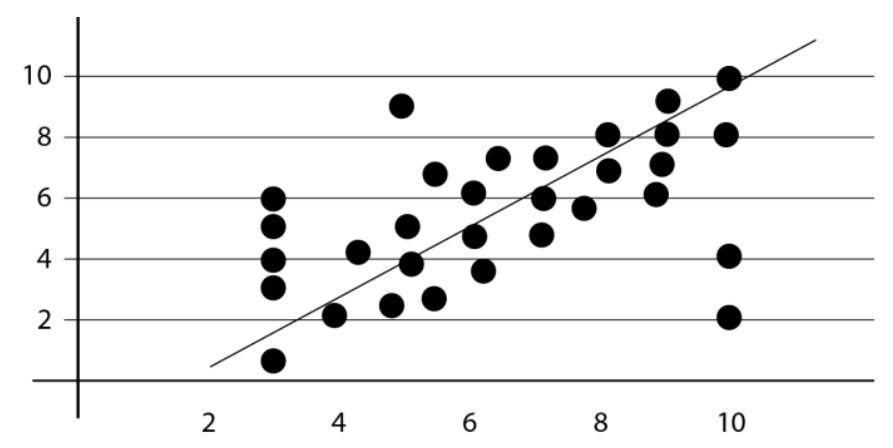

Table 3

Question no 13.Assessment of the global length of the face.(table 4 )

The images considered "very good looking" relate to a "normal length" in $68,4 \%$ of the cases, while "normal" images relate to normal and elongated answers was only $41 \%$ and $38 \%$ respectively.

"Ugliness" is associated to very long faces (37\%) or very short faces (40\%), meaning a $77 \%$ considers the face "very ugly" if it's seen as "very long" or "very short".

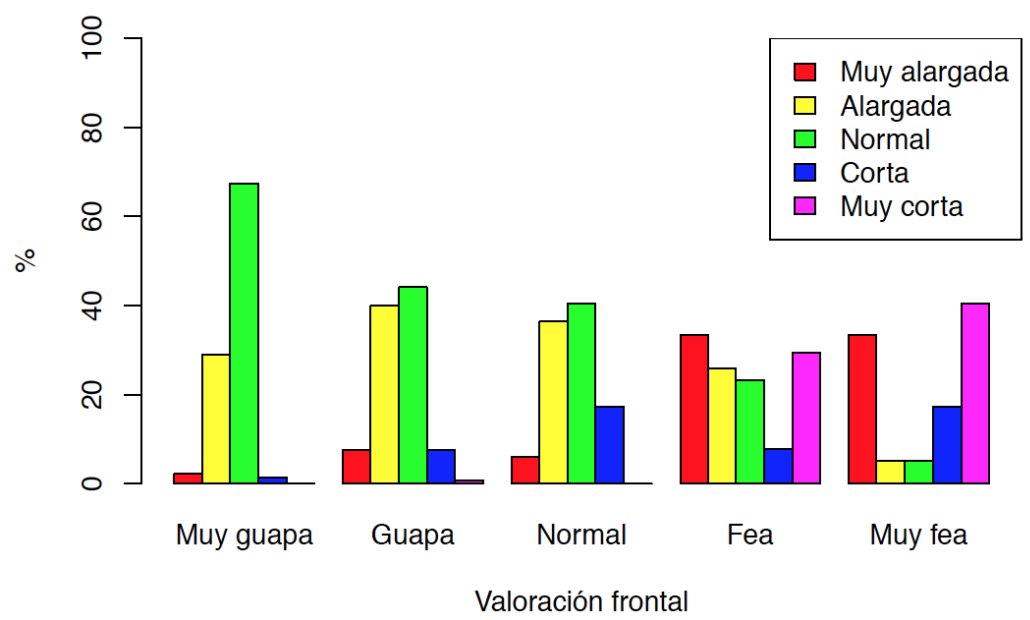




\section{Table 4}

Pregunta no 14 . Width of the face (table 5)

$82 \%$ of the survey respondents links a very narrow face to "ugly" $(42 \%)$ or "very ugly" $(40 \%)($ Table 5$)$, while $91 \%$ ties to beauty faces considered "wide" (34\%), "normal" (43\%) or "narrow" (14\%).

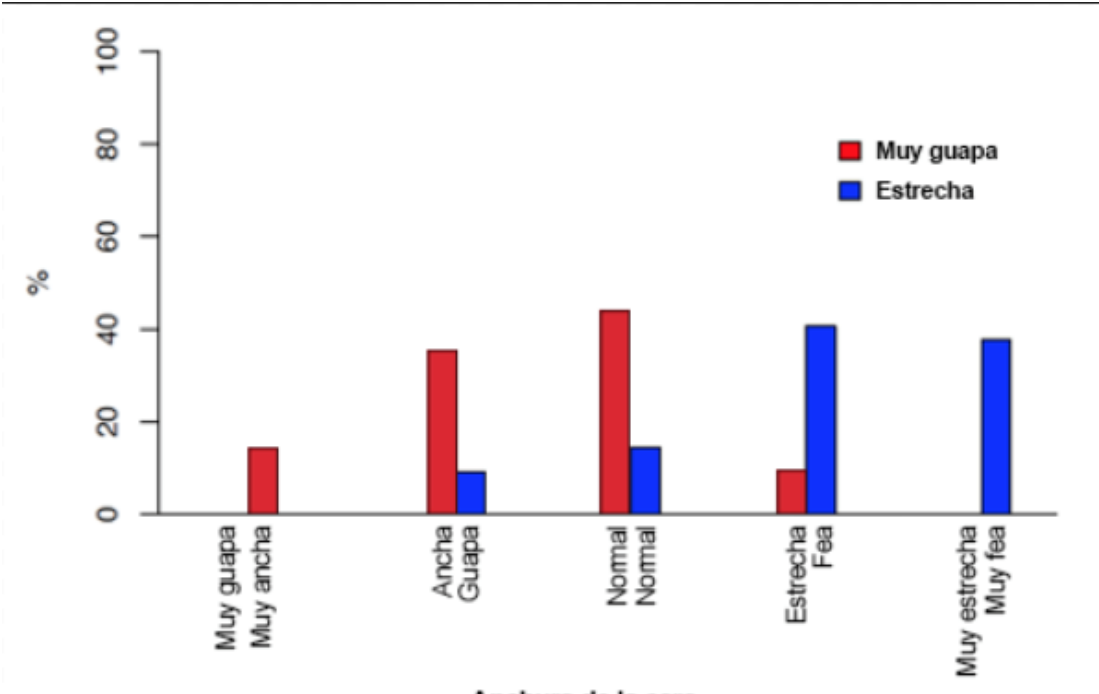

Anchura de la cara

Valoración frontal

Table 5

Question no $\mathbf{1 5}$. What third of the face looks dominant? (table 6,)

Beauty is related to balanced faces or to faces dominated by the upper third of the face in $76,4 \%$ of the cases. However, $98 \%$ of the people that consider the image as "very ugly" (68\%) or "ugly" (30\%) reckon that the lower third dominated the image. As the importance of the lower third of the face increases, so does the perception of ugliness. 


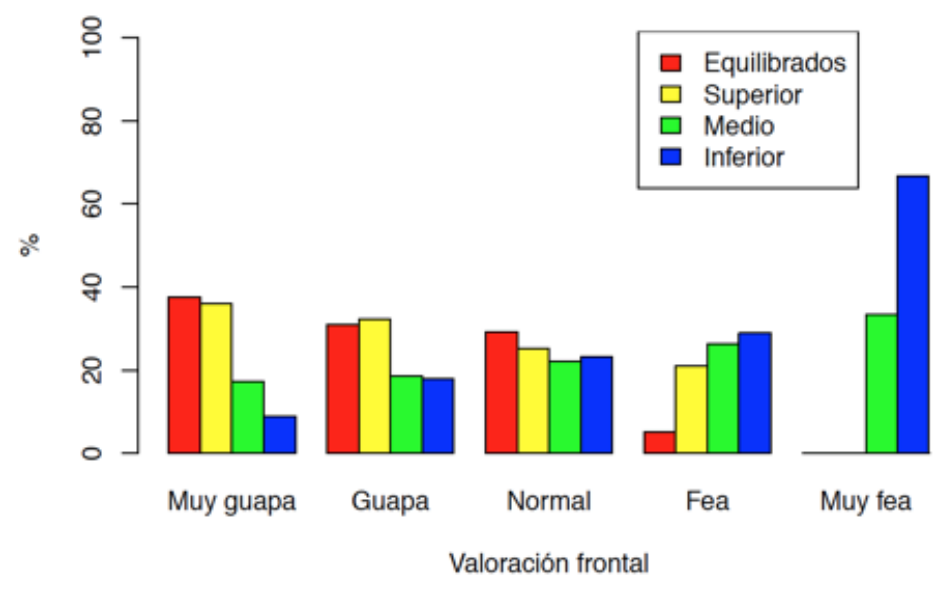

Tabla 6

Pregunta 16.Sideviews assessment (table 7)

Over $98 \%$ of the respondents that deemed the model on the picture as "very good looking" considered she had a "very beautiful" profile with a "normal" length.

This percentage lowers considerably for the rest of the cases: almost $100 \%$ of the people that considered the model as "very ugly" deemed the profile to be "very ugly"..

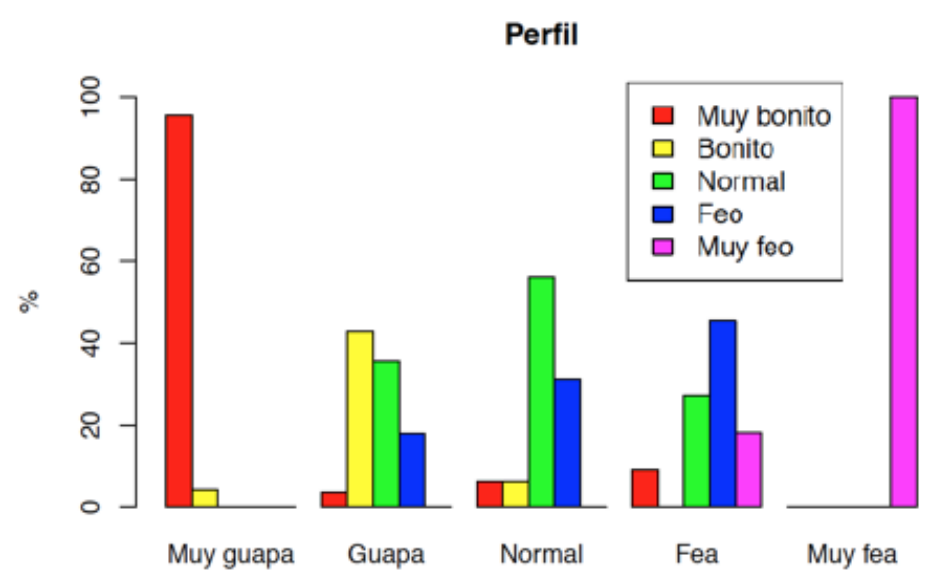

Table 7

Question no 28. Assessment of the length of the face sideways (table 8)

$0 \%$ of the respondents identifies a normal-length face as "very ugly", while $90 \%$ of them consider "very good looking" the faces with "normal" length. 


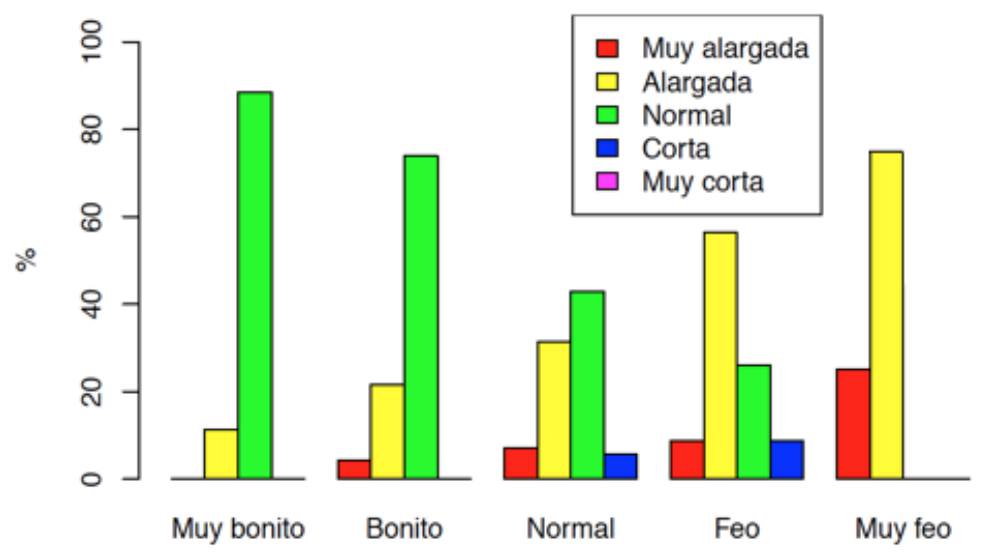

Table 8

Question $\mathrm{n} \times 2$ 29. Assessment of the beauty in relation to the face sideways (table 9 and 10)

Ugliness is related to a very sunk or prominent side-view in $89 \%$ of the cases. The prominent profile was considered ugly (40\%) and very ugly for the $49 \%$.

$0 \%$ considered very ugly when the profile was considered normal.

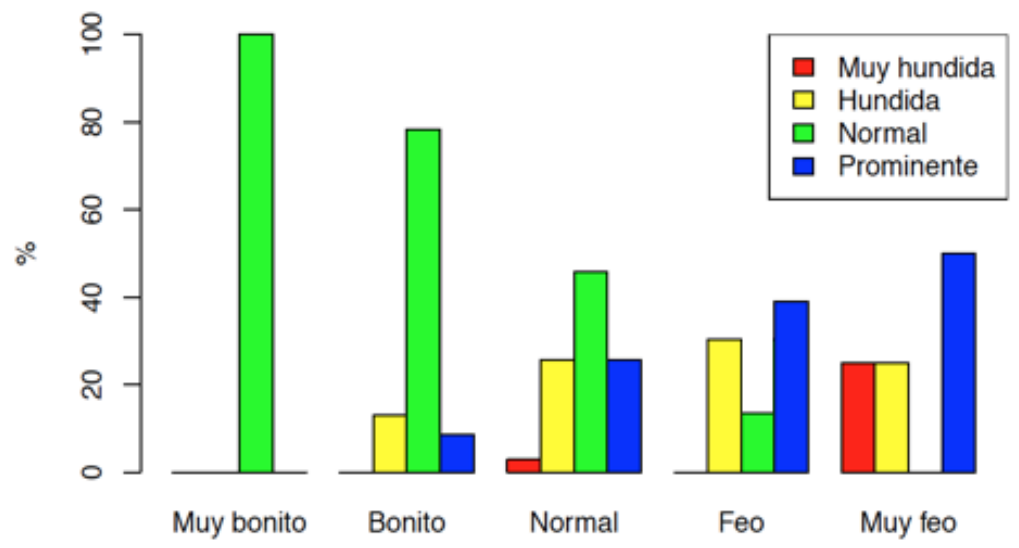

Table 9

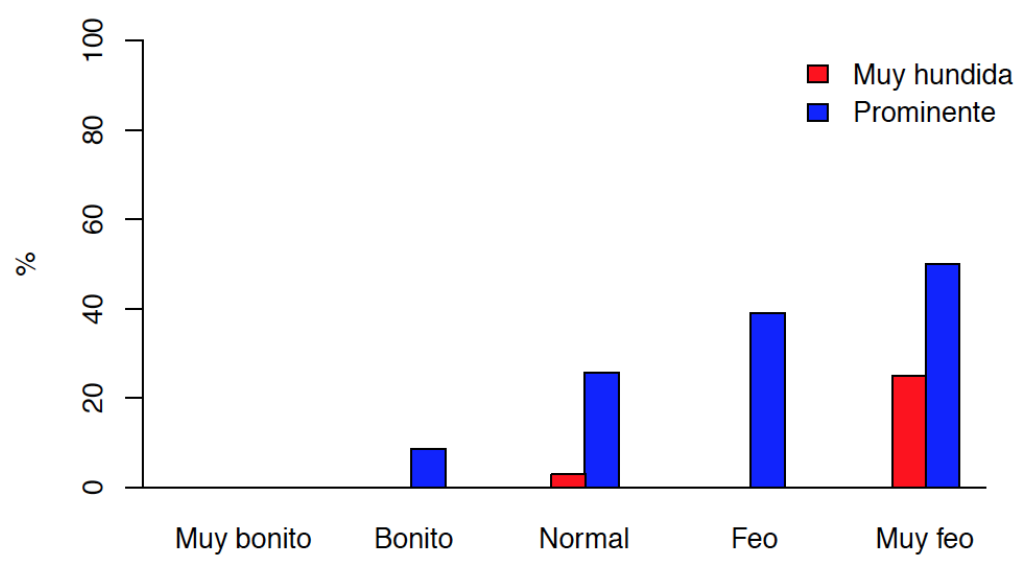




\section{Table 10}

$0 \%$ of the respondents that consider the profile as "very prominent" think the model is "very good looking".

II. Study of the front $(3,18)$.

Question no 3-18. What do you think of the front in the frontal view? (table 11)

A small or very small front is related to ugliness (82\%) and a normal or large one to beauty $(76,5 \%)$.

In the side view $91 \%$ small or very small front with ugly or very ugly.

$0 \%$ related small front with very beauty.

Valoración visión frontal

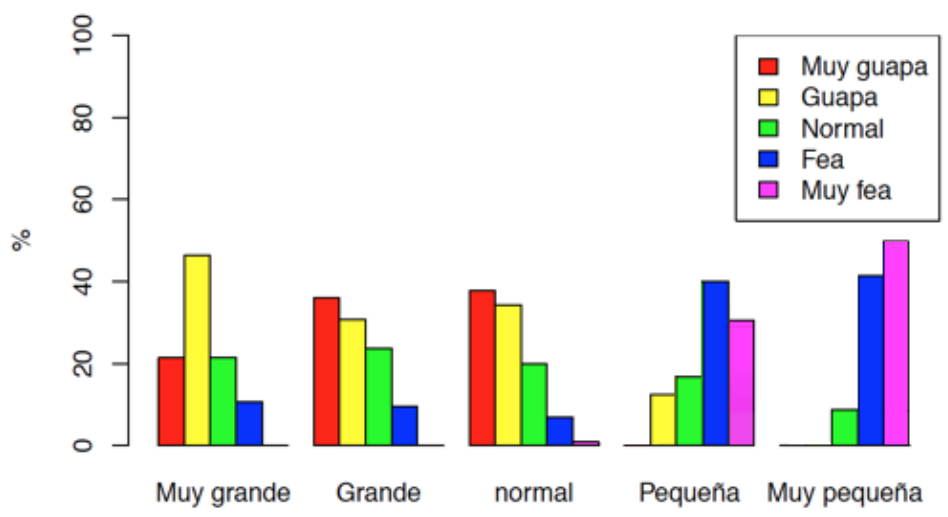

Table 11

III. Study of the eyebrows (5).

Almost $80 \%$ of the people who thought the models were "very good looking", "good looking" or "normal" considered that the gap between the eyebrows and their size was "normal". When the models were seen as "ugly" or "very ugly", over $100 \%$ thought that the eyebrows were too close.

IV. Study of the eyes (6-20).

Almost $57 \%$ of the people who considered that the model was "very ugly" thought that the eyes were small and $100 \%$ sunken or very sunken (table 19), whereas $100 \%$ of the people who thought she was "very good looking", "good looking" or "normal" reckoned the eyes were of "normal" size or big size. 
Question no 20. What do you think of the eyes? (Table 12)

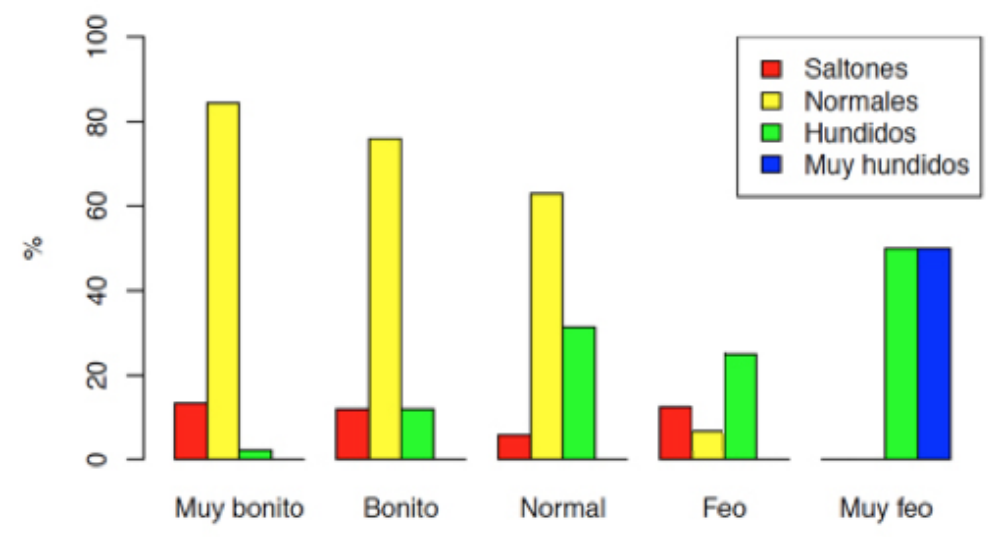

Table 12

V. Study of the nose $(7,8,21,22)$.

$97,3 \%$ of the surveyed that thought the model was "very good looking", "good looking" or "normal" considered the size of the nose was "normal" or "small", but if they considered her "very ugly", almost 100\% thought the nose was "big" or "very big".

Regarding the width of the nose, almost $80 \%$ of the people who said it was "ugly" /"very ugly" concluded it was "very wide" and on the contrary, $75 \%$ of the people who said the model was "very good looking" considered the nose "very narrow".

Question no 7. Size of the nose in the frontal view (table 13).

Large or too large noses are associated with ugliness and small or normal noses to beautiful or very beautiful. 


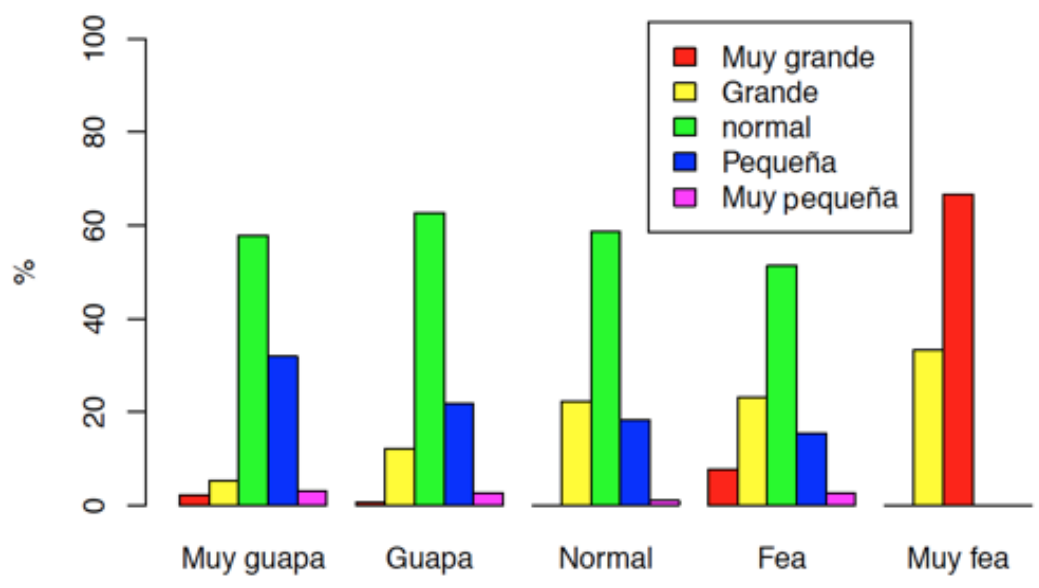

Table 13

Question no 8. Width of the nose (table 14).

"Very wide" noses are considered "ugly" or "very ugly" (80\%) and "normal" or "narrow" ones, "good looking" or "very good looking" (70\%). "Very narrow" noses are never considered as "ugly" or "very ugly".

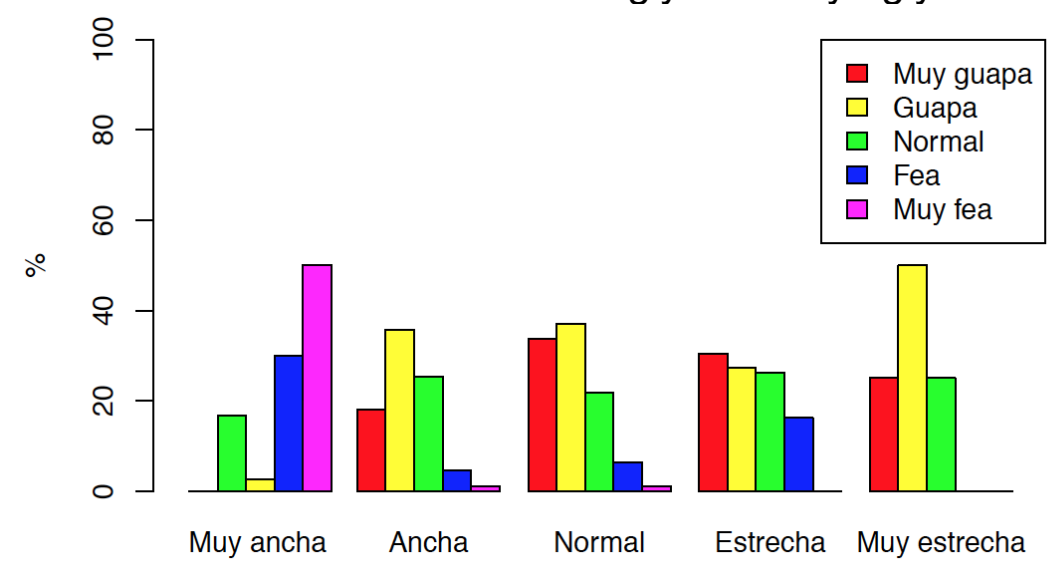

Table 14

VI. Study of the lips $(9,10,22,24,25)$.

Question no 9. Regarding the thickness of the lips (table 15, 16)

$100 \%$ of the surveyed that qualified the model as "very ugly" stated that the lips were thin or very thin. However, almost $95 \%$ of the ones that qualified the model as "very beautiful" stated the lips were normal, big or very big. 


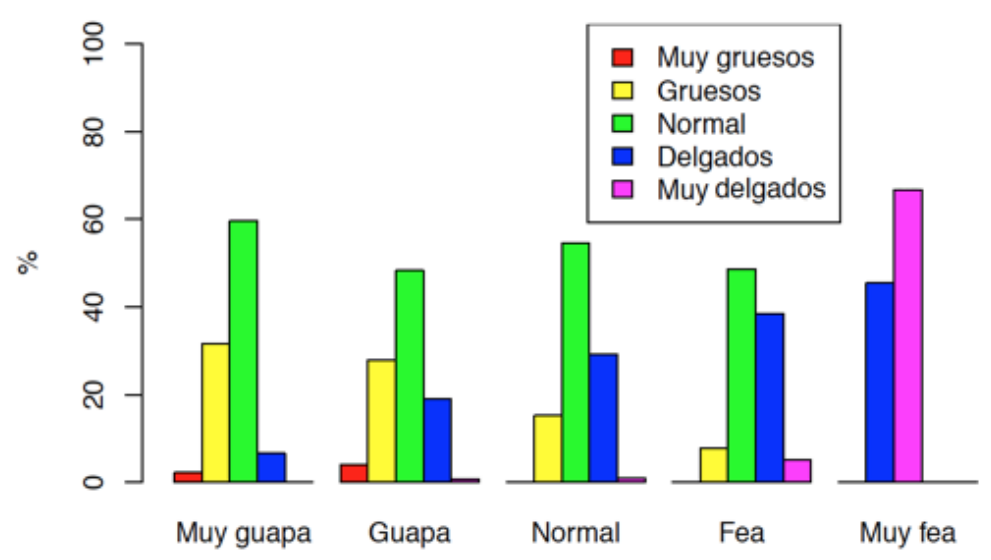

Table 15

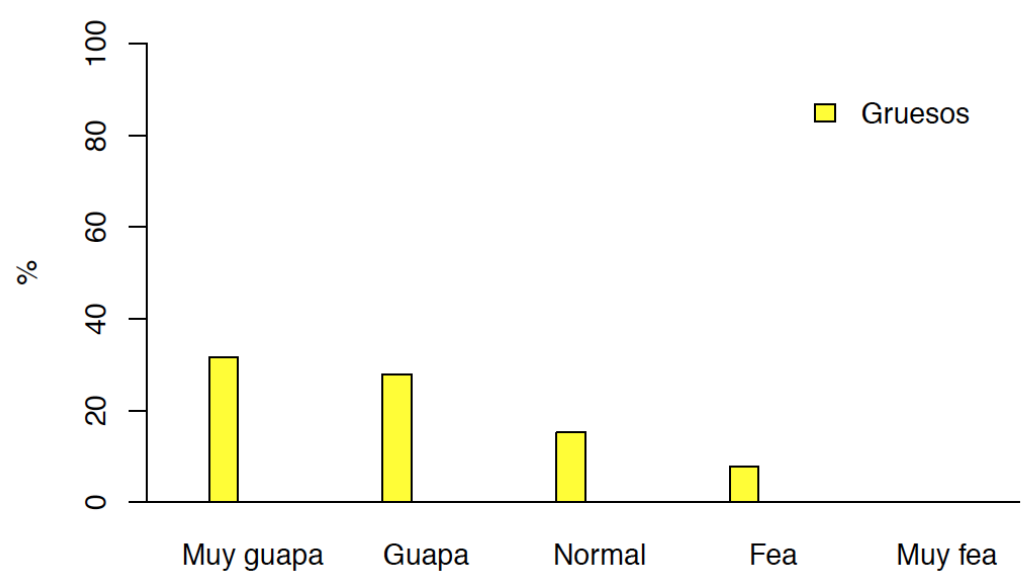

Table 16

$0 \%$ of the people that qualified the lips as "thick" thought the model was "very ugly". (table 26)

Question no 10. About the protrusion of the lips. (Table 17)

$85 \%$ of those who qualified the lips as protruded associated it to a "very good looking" model.

$100 \%$ of the surveyed reckoned the model was "very ugly" when her lips on the picture were sunken or very sunken.

$0 \%$ of those who qualified the lips as protruded associated it to a very ugly. 


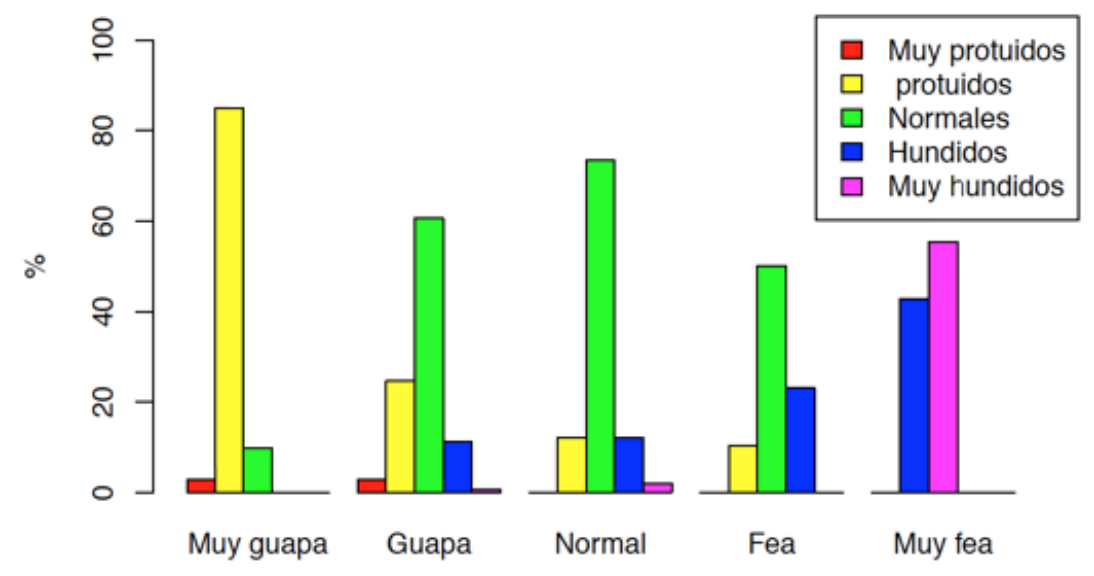

Table 17

Question no 23. Appraisal of the upper lip. (table 18)

$80 \%$ of the surveyed associated a "very beautiful" model to a thick upper lip and $0 \%$ associated it that qualification to a very thin lip.

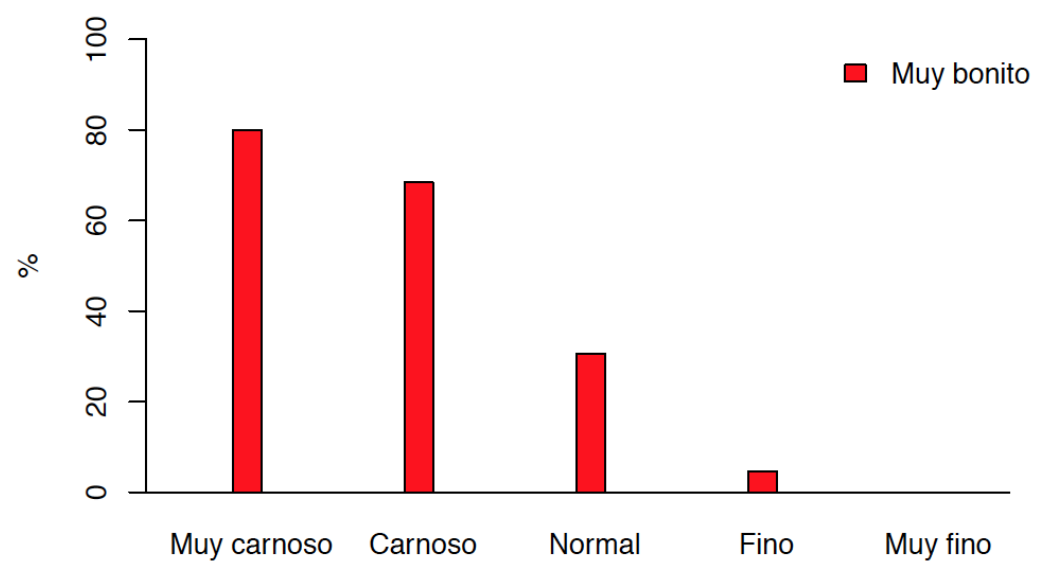

Table 18

Question no 24. Protrusion of the upper lip.(table 19)

For $79 \%$ de los encuestados Sunken lips are considered "very ugly" and the ones slightly protruded or normal are considered beautiful. (100\%) 


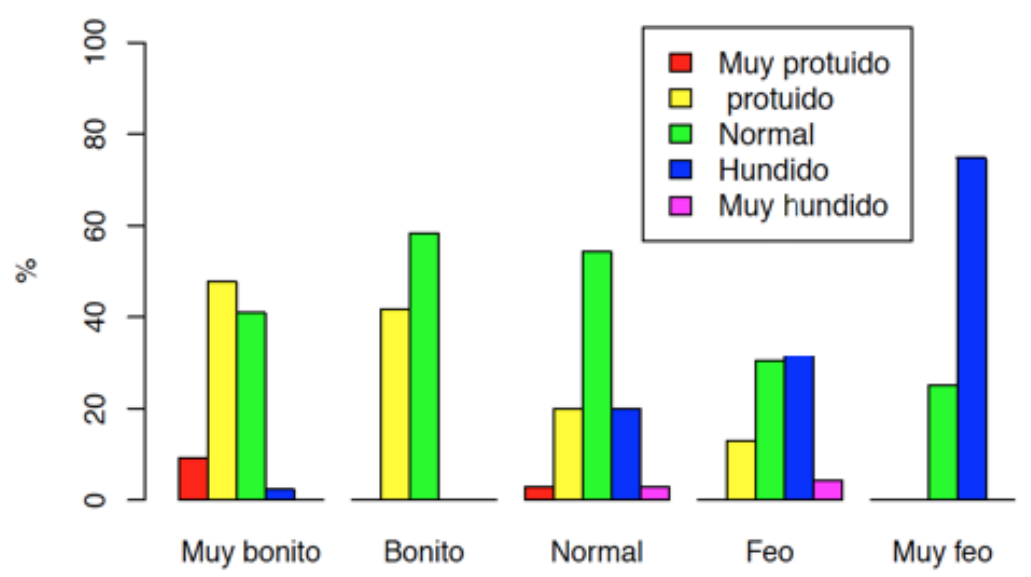

Table 19

VII. Study of the smile (11)(26).

Almost $98 \%$ of those who consider the model "very good looking-good looking-normal" thought the smile was "very beautiful". Similarly, $87 \%$ of those who thought the model was "very ugly-ugly" considered the smile as "very uglyugly".

Question 11. Smile appraisal. (Table 20 and 21)

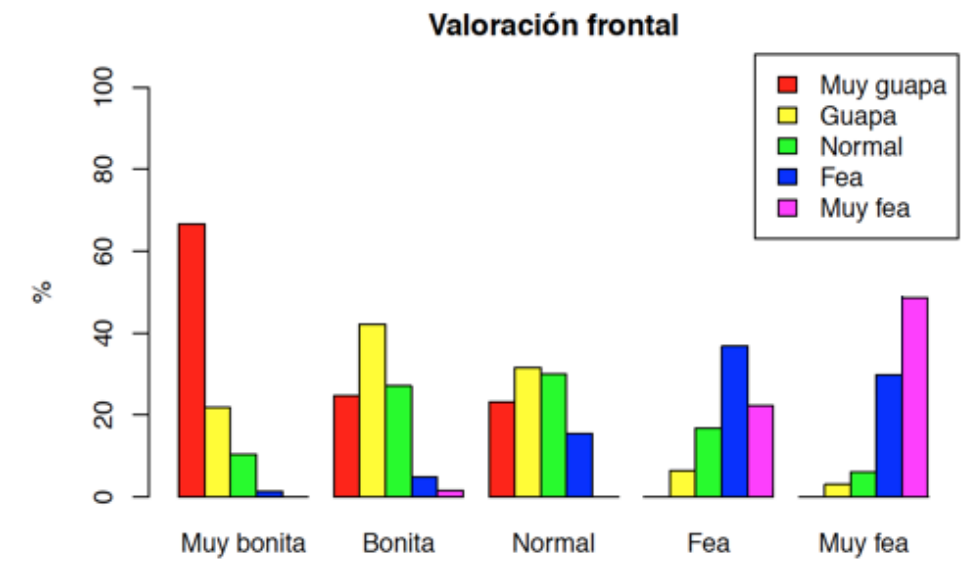

Table 20 


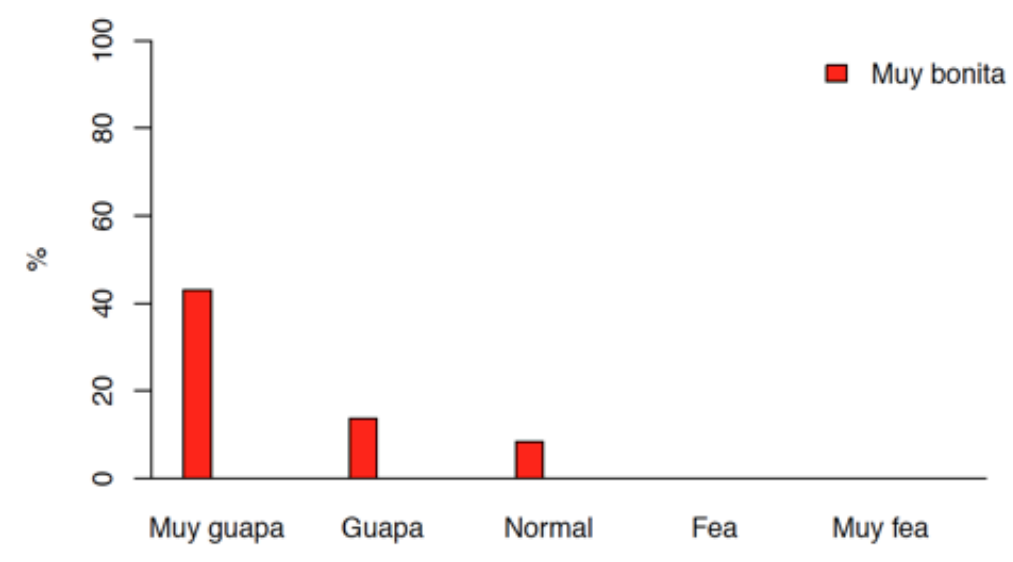

Table 21

$0 \%$ of the people that qualified the smile as "very beautiful" considered the model to be very ugly.

Question no 26. Smile Appriaisal (side view). (Table 22)

$100 \%$ of the people that considered the smile to be ugly or very ugly stated the profile of the model to be "beautiful".

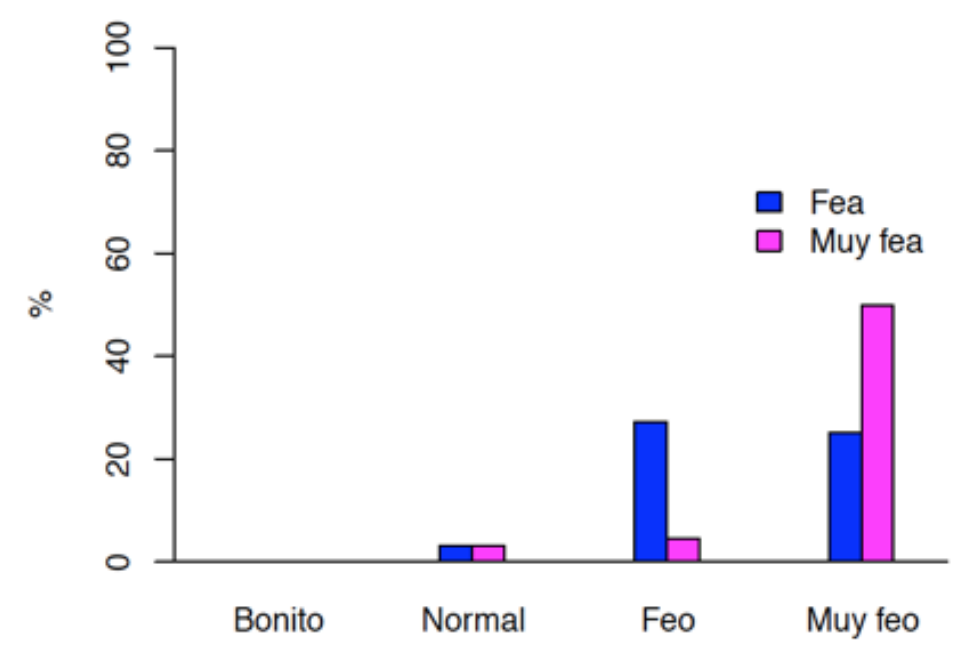

Table 22

VIII. Study of the chin $(12,27)$.

A very prominent chin or very retracted is considered "ugly" or "very ugly" at every occasion.

Question no 12. About the chin. (Table 23)

$94 \%$ of the surveyed that consider the chin as normal or slightly protruded qualified the model as "very beautiful". Almost $100 \%$ of the people that qualified the chin as "very prominent" or "very sunken" qualified the model as ugly or very 
ugly.

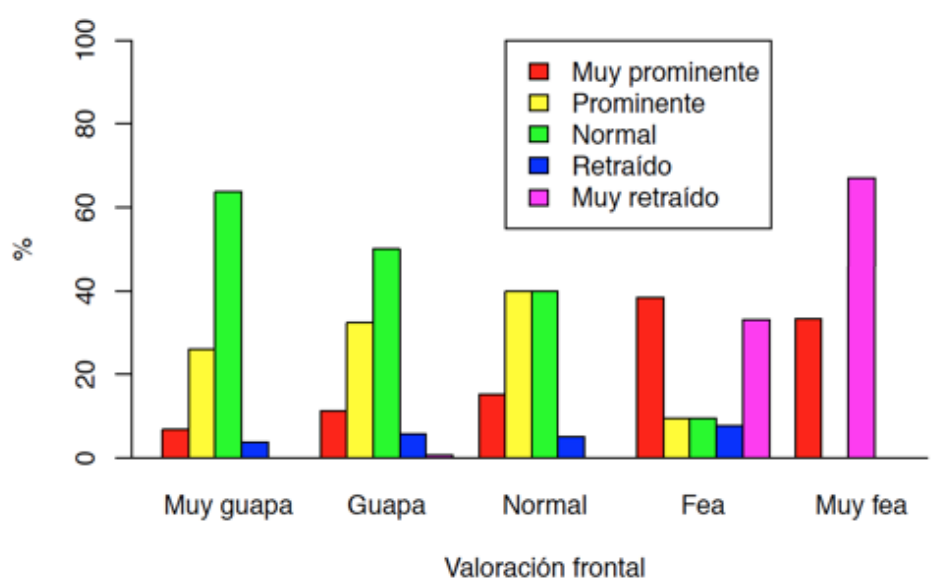

Table 23

IX. Study on the predisposition to undergo a surgical intervention $(30,33)$

$95 \%$ of those who considered the model to be "very good looking-good looking" didn't think they would want to be operated on if it was them. However $70 \%$ of those who deemed the model to be "ugly-very ugly" thought they would.

Question no 30. If you were the person on the picture, would you like to be operated on? (Table 24)

When we relate the wish to be operated on with the appreciation of beauty we obtain a "Kendall's Rank Correlation Tau" of 0,825.

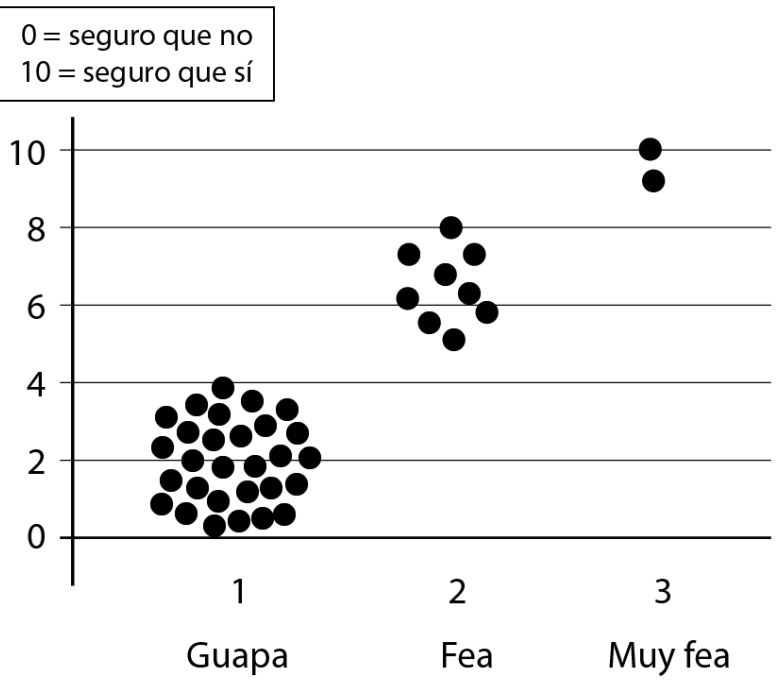

Table 24

Question no 33. (table 25) 
If we limit the posible answers to the former question to a yes/no option, $82.43 \%$ of the surveyed would not like to be operated on and $17.57 \%$ would, considering that $95 \%$ gave a negative answer when the model was seen as "very good looking" and $80 \%$ gave a positive one when she was seen as "very ugly".

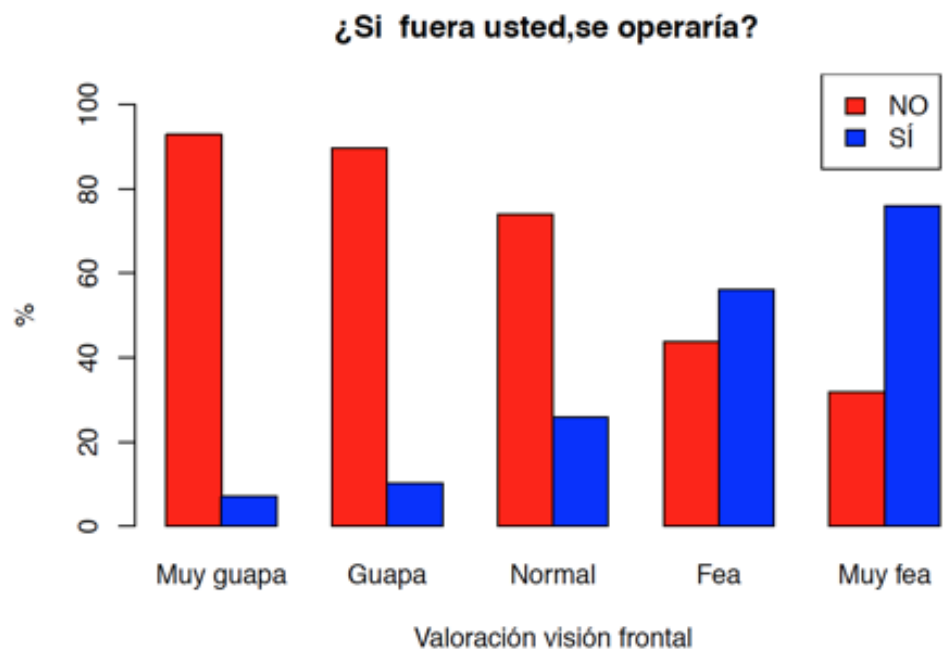

Table 25

\section{II.b. Analysis of the Golden Ratio according to Rickets.}

\section{Method design and population of the study.}

\section{a. Candidate election.}

The study designed was descriptive. 65 feminine models and 50 masculine models of White ethnicity aged 18 to 60 that appeared on fashion magazines were picked. Measurements were made in December 2015.

b. Election of proportions.

Six proportions were measured according to Rickets and an additional seventh on side-faced pictures.

1. Trichion - Pupil To Pupil - Chin.

2. Trichion - Base of the Nose To Base of the Nose - Chin.

3. Bi-Pupil line - Base of the Nose To Base of the Nose-Chin.

4. Bi-Pupil line - Lip Corner To Lip Corner - Chin.

5. Bi-Pupil line - Base of the Nose To Base of the Nose - Lip Corner.

6. Base of the Nose - Lip Corner To Lip Corner - Chin.

7. Base of the Ear - Lateral Cantus To Lateral Cantus - Base of the Nose.

c. Data Processing. 
A database was prepared on an Excel spreadsheet using the 7 measurements on each picture and it was then exported to the statistical package R.3.2 for Windows.

\section{d. Statistical Analysis.}

\section{d.1. Correlation calculations.}

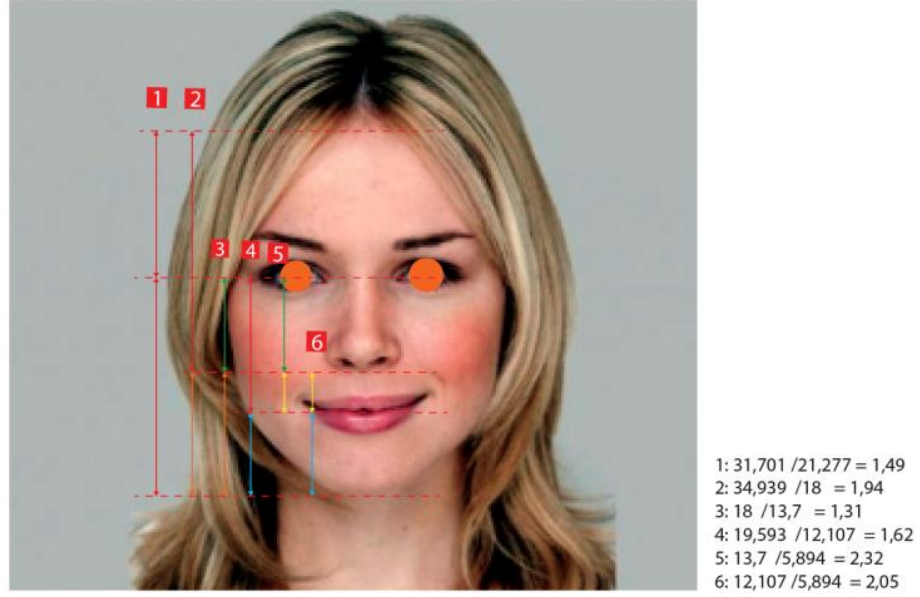

Figure 11

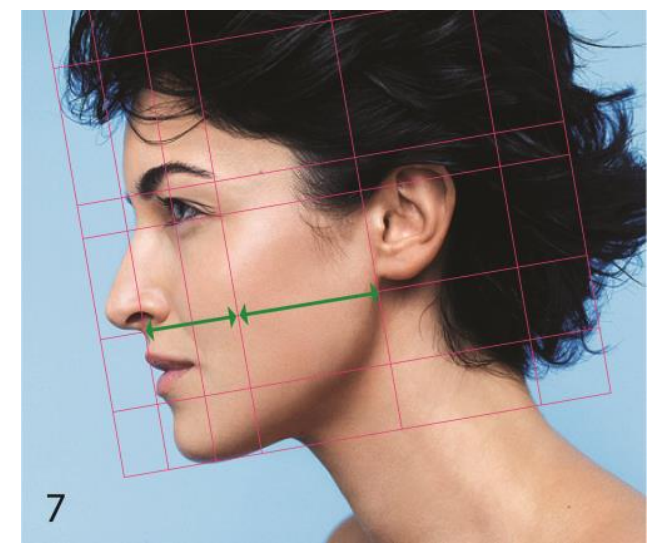

Figure 12

\begin{tabular}{|l|c|c|c|c|c|c|}
\hline & PD1 & PD2 & PD3 & PD4 & PD5 & PD6 \\
\hline PD1 & 1.00 & -0.55 & 0.10 & -0.19 & 0.01 & 0.22 \\
\hline PD2 & -0.55 & 1.00 & -0.67 & 0.64 & 0.52 & -0.23 \\
\hline PD3 & 0.10 & -0.67 & 1.00 & -0.58 & -0.63 & 0.06 \\
\hline PD4 & -0.19 & 0.64 & -0.58 & 1.00 & 0.16 & -0.59 \\
\hline PD5 & 0.01 & 0.52 & -0.63 & 0.16 & 1.00 & 0.54 \\
\hline PD6 & 0.22 & -0.23 & 0.06 & -0.59 & 0.54 & 1.00 \\
\hline
\end{tabular}

Table 26

The 2 most correlated variables are PD2 and PD3, with a correlation of -0.67 and the least correlated are PD1 and PD5.

For $\mathrm{N}=115$, from 0.4 onwards the Pearson correlation coefficient is significant at $99 \%$.

Graphically: 

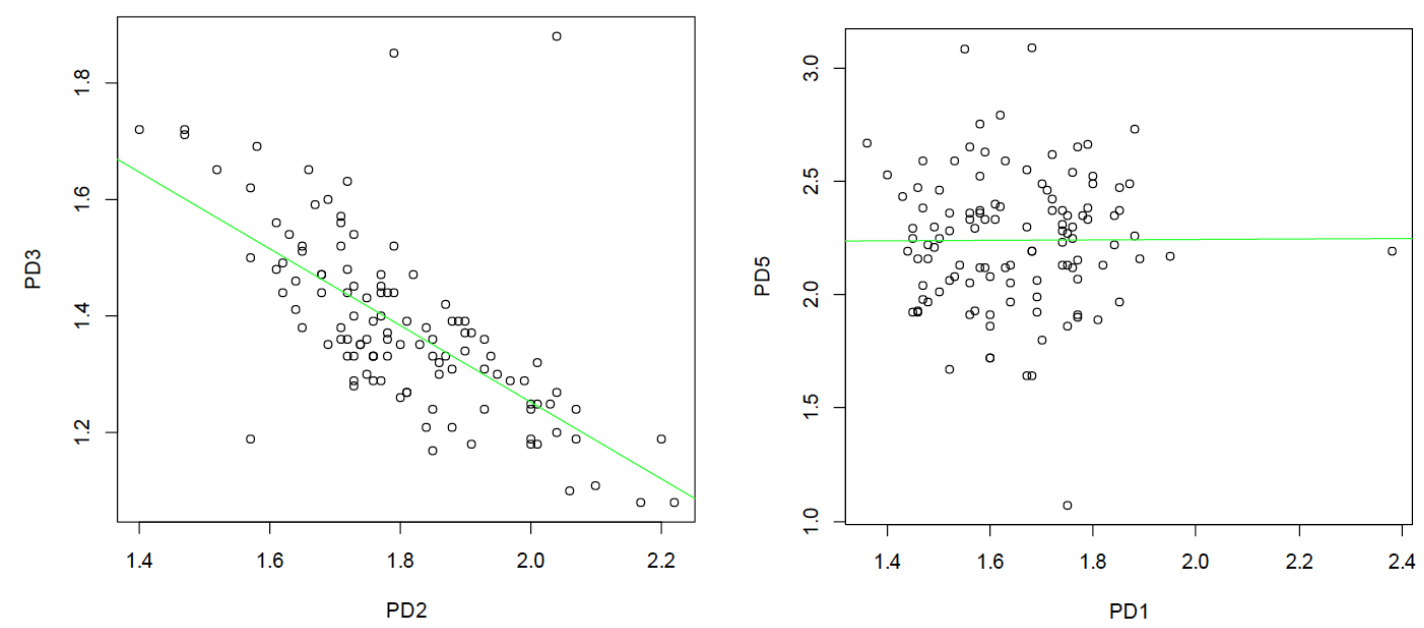

\section{Table 27}

Considering the sex of the models:

For men ( $\mathrm{N}=50)$, data is significant at $99 \%$ from a coefficient of 0.5 and in women $(\mathrm{N}=65)$, it is so from 0.45 .

\begin{tabular}{|l|l|l|l|l|l|l|l|l|l|l|l|l|}
\hline & \multicolumn{9}{|c|}{ HOMBRES } & \multicolumn{7}{c|}{ MUJERES } \\
\hline & PD1 & PD2 & PD3 & PD4 & PD5 & PD6 & PD1 & PD2 & PD3 & PD4 & PD5 & PD6 \\
\hline PD1 & 1.00 & -0.56 & 0.07 & -0.11 & 0.03 & 0.09 & 1.00 & -0.36 & 0.05 & -0.06 & -0.04 & 0.06 \\
\hline PD2 & -0.56 & 1.00 & -0.81 & 0.70 & 0.42 & -0.26 & -0.36 & 1.00 & -0.68 & 0.59 & 0.70 & -0.03 \\
\hline PD3 & 0.07 & -0.81 & 1.00 & -0.74 & -0.66 & 0.16 & 0.05 & -0.68 & 1.00 & -0.55 & -0.62 & -0.01 \\
\hline PD4 & -0.11 & 0.70 & -0.74 & 1.00 & 0.10 & -0.74 & -0.06 & 0.59 & -0.55 & 1.00 & 0.24 & -0.49 \\
\hline PD5 & 0.03 & 0.42 & -0.66 & 0.10 & 1.00 & 0.52 & -0.04 & 0.70 & -0.62 & 0.24 & 1.00 & 0.57 \\
\hline PD6 & 0.09 & -0.26 & 0.16 & -0.74 & 0.52 & 1.00 & 0.06 & -0.03 & -0.01 & -0.49 & 0.57 & 1.00 \\
\hline
\end{tabular}

Tabla 28

PD1 does not have a strong correlation in both sexes with any other variable. It's a measurement that will need to be studied.

PD2 is correlated in both sexes with PD3 and PD4, although the correlations are stronger among men. Hence we could consider studying only one of the 3 variables. 

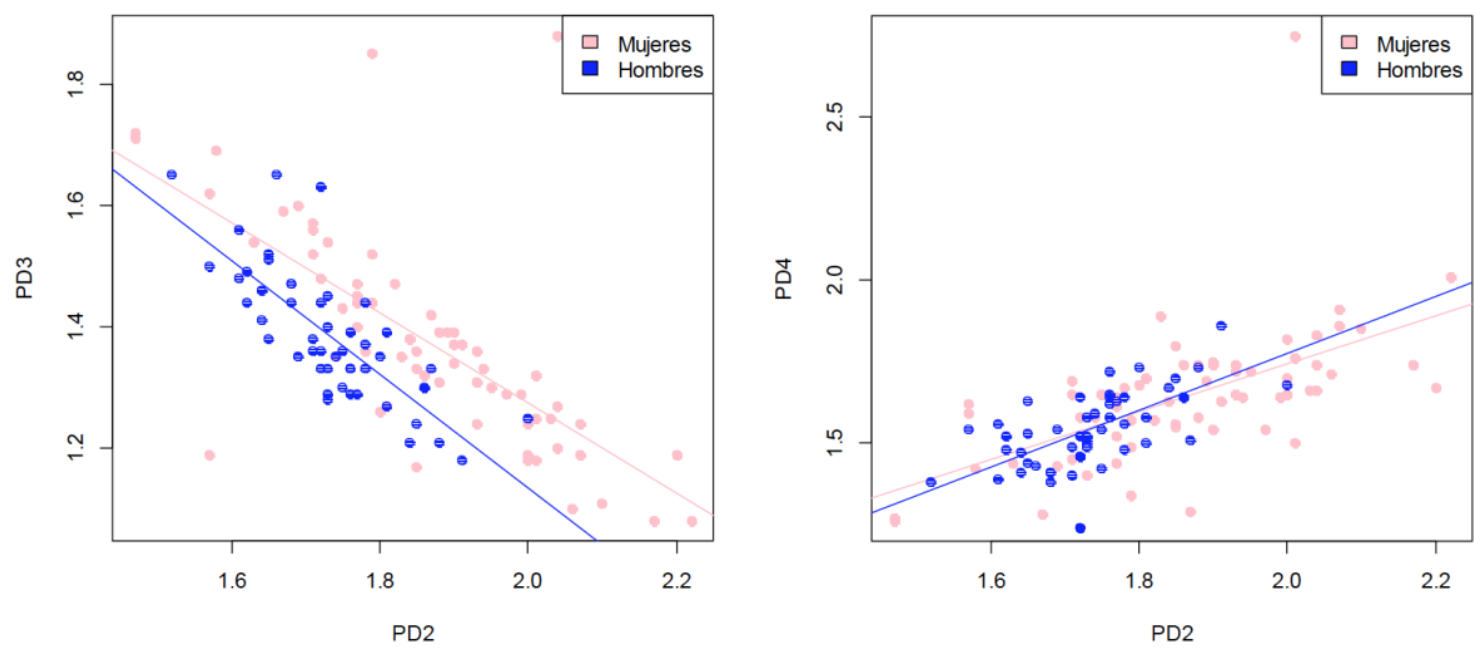

Table 29

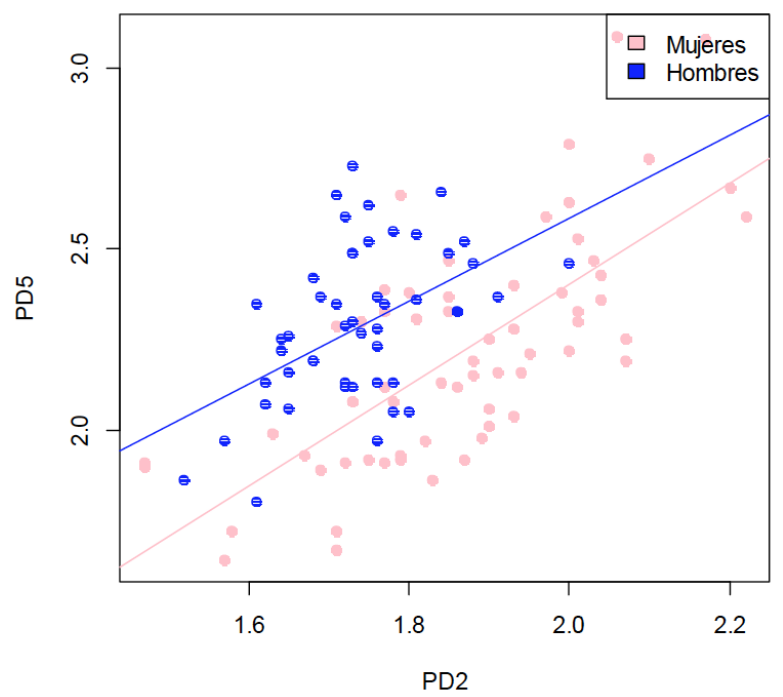

Table 30

PD5 and PD6 have a correlation stronger than 0.5 in both groups.

Graphically: 


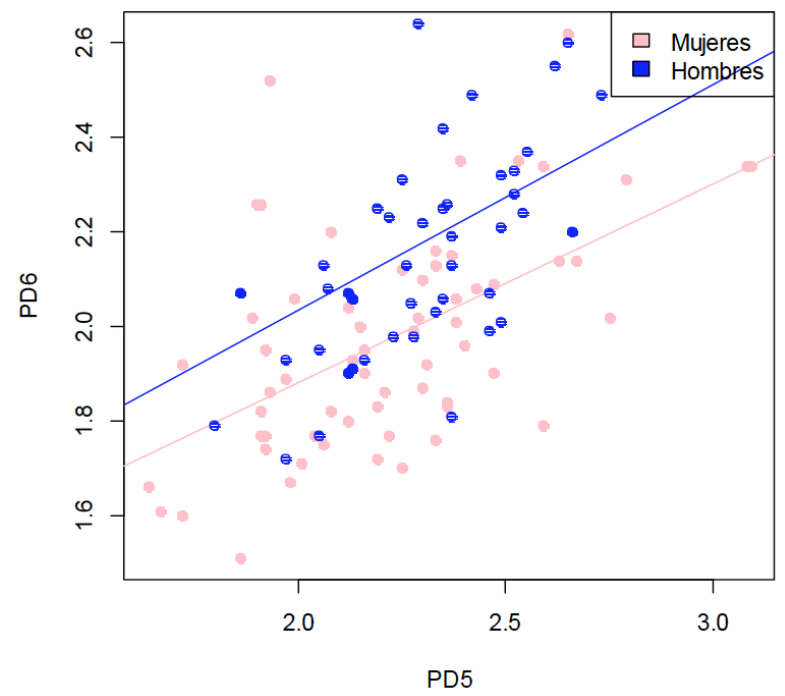

Table 31

\section{d.2. Analysis of main components}

For the data on men: with 3 main components we can explain $97 \%$ of the data variability:

- First main component: refers to the variables PD2, PD3 and PD4, $49.22 \%$ of the variability explained.

- Second main component: refers to the variables PD5 and PD6, 29.57\% of the variability explained.

- Third main component: refers to the variable PD1, $18.43 \%$ of the variability explained.

Fort he data on women: with 3 main components we can explain $91 \%$ of the data variability:

- First main component: refers to the variables PD2, PD3 and PD4, $46.66 \%$ of the variability explained.

- Second main component: refers to the variables PD5 and PD6, 26.93\% of the variability explained.

- Third main component: refers to the variable PD1, $17.12 \%$ of the variability explained

\section{III.DISCUSSION.}

III.1. Analysis of the survey on facial normality

Questions 1, 2,13,14,15,16,17, 28 y 29 study the perception of harmony and facial balance.

The first and the second questions lead us to think, just like Perret did (20), that not everyone has the same criteria for the same picture, but if we add the statements "very good looking", "good looking" and "normal", the resulting "normality" interval stands for $90.07 \%$ of the answers, which is why we can state that, like Duggal (2016)(6), that there is a "facial normality".

Anìc Milösevíc (2011)(22) found however that such facial beauty standard 
applicable to the different White populations did not exist. In his study almost all the variables relating to soft tissues showed significant differences $(P=0.000)$ between Croatian and White American women, except for TVL-NT (0.096). Among men, the nose-lip angle was the only variable that didn't show a significant statistical difference between the two populations.

A face of normal length or slightly long (questions 13 and 28) is related to beauty and the very long ones or very short ones with uglyness.

Michiels (1994)(35) studied the facial attractiveness of White women observing how the vertical measurement increased and the class II became more important.

With regards to the width of the face (Questions $14 \& 16$ ), the "very good looking", "good looking" and "normal" show a normal width or a slightly wide one, while the "ugly" or "very ugly" faces are either too narrow or too wide.

When correlating variables on frontal and side-view balance (questions 2 and 17, "Kendall's rank correlation Tau") we see that the hypothesis of correlation is true because the parameter is different to $0(0.635)$.

The symmetry was studied by Prokopakis (2013) (9). In our study it wasn't considered. Soler (2012) (27) found out that among Spaniards, a certain degree of asymmetry with a right side prominence was considered as attractive among men. Similarly, Swaddie (1995) (36) states that symmetry is not always a synonym for beauty.

Even if through some symmetry we obtain beauty, a perfect symmetry displeases and is associated to an artificial face, cold and missing humanity.

The side view (question 16) is tightly linked with beauty by considering "very beautiful" the people with a "very beautiful" side view and as "very ugly" those with an equally ugly side view.

As the side view evolves towards "very prominent" or "very sunken", the perception of ugliness increases. Meici Filho (2007)(16) carried out an interesting study modifying the side view of 5 pictures with the programme Deformer 2.0 and making a before/after comparison when adapting it to a ratio close to 1.618. The Chi-Square technique revealed a positive correlation between the Golden Ratio and the aesthetic appreciation. Knight (2005) (19) observed that it was considered less attractive for increments of over 5 degrees of the ANB angle and that an increase in the bottom third length of the face was considered less attractive in women, while a decrease in that length made men less attractive. Erbay, (2002) (32), studying Anatolic turkish women, defined as an attractive side view people with a small nose, protruded lips (according to the Ricketts norm) and a slightly sunken side view.

If we analyse the balance between the 3 thirds of the face (question 15), we see how balanced faces match "very good looking" people and unbalanced ones match "very ugly" people. 
Johnston (2005) (25) found out that a decrease in the lower third was perceived as more attractive than the images with an increased lower third. Sheideman (1980) (31) adds that the length of the horizontal soft tissues of the mandibular protuberance has an effect similar to the one explained about the thirds.

Mesaros (2015)(36), evaluating attractiveness using a questionnaire with images found it more attractive when the top third is dominant and less attractive when the bottom third is dominant. This goes in hand with the inverse correlation between beauty perception and the desire to be operated (question 33).

The front was studied on questions 3 and 18.

It was considered "normal" ("very good looking" + "good looking" + "normal") in $57 \%$ of the cases. When the front was big or normal, the model was seen as "very good looking" and then as it became smaller it was seen as uglier.

The eyebrows were covered on questions 4, 5 and 19.

Regarding their width, they were considered "normal" ("very good looking" + "good looking" + "normal") in $62 \%$ of the cases.

Eyebrow gap (question 5)

It's considered "normal" in $79 \%$ of the cases. As it becomes narrower, the percentage of "ugly" and "very ugly" answers increases.

Eyes (question 6)

There is a clear correlation between size and beauty on the one hand and between how sunken they are and ugliness on the other (question 20).

The size and magnitude of the sunk are inversely correlated with beauty and harmony.

Normal or big eyes are seen as "good looking" or "very good looking" and the small or sunken ones as "ugly" or "very ugly".

Anca (2005)(36) considers them the most important element in beauty perception.

In our study we haven't considered the effect of the distance between them: Faure (2002) (23) modified through "morfing" that distance and discovered a negative effect on facial aesthetics as it increased. The effect was found significant using ANOVA, T_test, $(P<001)$ techniques.

The nose is studied in questions 7 and 21.

The normal or slightly small noses are considered as "very good looking" 
or "good looking" and the big or very big ones as "ugly".

When studying its width (question 8), beauty is associated with normal or narrow noses.

Devcic (2011)(26), when studying the relationship between nasal projection and facial attractiveness found a positive correlation with the ideal measurements proposed by Good and Crumley and no correlation with the ones proposed by Simons, Baum and Powell.

The lips were studied on questions 9,10, 23, 24 y 25.

Normal or thick lips are associated with beauty and thin or very thin lips with ugliness.

Regarding protrusion (question 24) the relationship between "very good looking" /"good looking" and protruded or very protruded lips is evident, which goes together with the study of Yu Xin (2016)(24).

Modarai (2013) (30) studied the position of the lower lip in relation with the chin and found out that a protrusive position of the lower lip is usually preferred.

Questions 11 and 26 make reference to the smile, showing a great percentage $(70 \%)$ that associates a "very good looking" model with a "very good looking" smile.

Murthy (2008)(7) discovered that $25 \%$ of the "good looking" smiles followed the Golden Ratio when referred to their width on a frontal view.

However, Mahshid (2004)(15) couldn't find any correlation between the Golden Ratio and an aesthetically pleasant smile.

The chin is studied on questions 12 and 27 in which we notice a $60 \%$ of cases where a normal or slightly protruded chin referred to a "normal"/"good looking" or "very good looking" model.

Macías Gago (2012)(21), using the Wilcoxon's W non-parametric test (median comparison) technique, and Modarai (2013)(30) found out that more attractive women showed a jaw slightly backwards compared to the maxillary (tendency to Class II), while the males showed a more straight face with a prominent chin (tendency to class III).

The chin, the upper lip and the nose were the parts with a biggest impacto $n$ beauty appreciation.

Lastly, Nomura (2009)(34), when studying the side view of the face found big differences $(P<0,001)$ depending on the ethnicity and sex of the surveyed.

On the contrary, Zhao (2013)(17) found among the Han ethnic group proportions considered attractive similar to the ones in white populations. 


\section{III.2. Golden Ratio}

When checking the relationship between beauty and Golden Ratio, 2 goals were defined: to see if there is an interval within which there is a qualified majority and to see if there are correlations that allow a reduction of the number of variables.

\section{III.2.a. Correlation table}

The more 2 variables are correlated, the more the Pearson coefficient comes close to 1 or -1 . If they are independent, that coefficient will be 0 . The 2 variables more closely correlated are PD2 and PD3 $(-0.67)$ and the less correlated PD1 and PD5.

If we differenciate by sex, we can see that PD1 has no strong correlation with any other variable. PD2 is correlated in both sexes with PD3 and PD4. PD5 and PD6 have a correlation higher than 0.5 in both sexes as well.

The analysis of the main components allows us to reduce the dimensions, for men as well as for women, to 4 variables in the frontal images (PD1, PD2, PD5 and PD6), which account for $97 \%$ of the data variability and PP1 which refers only to side-view pictures.

III.2.b. Confidence Interval.

Pancherz (2010) (8) finds an interval comprised between 0.3 and 7.8 for men and 0.2 and 11.2 for women.

Jahanbis (2008)(14) obtains a value of 1.58 for Trichion - Pupil To Pupil - Chin and for Trichion - Base of the Nose To Base of the Nose - Chin.

In our study the intervals are different for each variable and sex. The values are shown on Table 53, which allows us to represent them on a pentagon to help visualise quickly the facial balance of the patient.

\begin{tabular}{|c|c|c|c|c|c|c|}
\hline & \multicolumn{3}{|c|}{ Hombres } & \multicolumn{3}{c|}{ Mujeres } \\
\hline & $90 \%$ & $95 \%$ & $99 \%$ & $90 \%$ & $95 \%$ & $99 \%$ \\
\hline PD1 & {$[1.56-1.90]$} & {$[1.53-1.93]$} & {$[1.47-1.99]$} & {$[1.34-1.83]$} & {$[1.29-1.88]$} & {$[1.20-1.97]$} \\
\hline PD2 & {$[1.56-1.89]$} & {$[1.53-1.92]$} & {$[1.46-1.99]$} & {$[1.59-2.13]$} & {$[1.54-2.19]$} & {$[1.44-2.29]$} \\
\hline PD3 & {$[1.20-1.59]$} & {$[1.16-1.62]$} & {$[1.09-1.70]$} & {$[1.09-1.66]$} & {$[1.03-1.72]$} & {$[0.92-1.83]$} \\
\hline PD4 & {$[1.32-1.74]$} & {$[1.28-1.78]$} & {$[1.20-1.86]$} & {$[1.30-1.99]$} & {$[1.23-2.06]$} & {$[1.10-2.19]$} \\
\hline PD5 & {$[1.82-2.72]$} & {$[1.73-2.81]$} & {$[1.57-2.97]$} & {$[1.69-2.73]$} & {$[1.59-2.83]$} & {$[1.40-3.03]$} \\
\hline PD6 & {$[1.76-2.57]$} & {$[1.68-2.65]$} & {$[1.52-2.80]$} & {$[1.58-2.36]$} & {$[1.51-2.43]$} & {$[1.36-2.58]$} \\
\hline
\end{tabular}

Tabla 48

We can see that, with a $99 \%$ confidence degree, the Golden Ratio is within virtually every interval $n^{\circ}$ table 51 . 


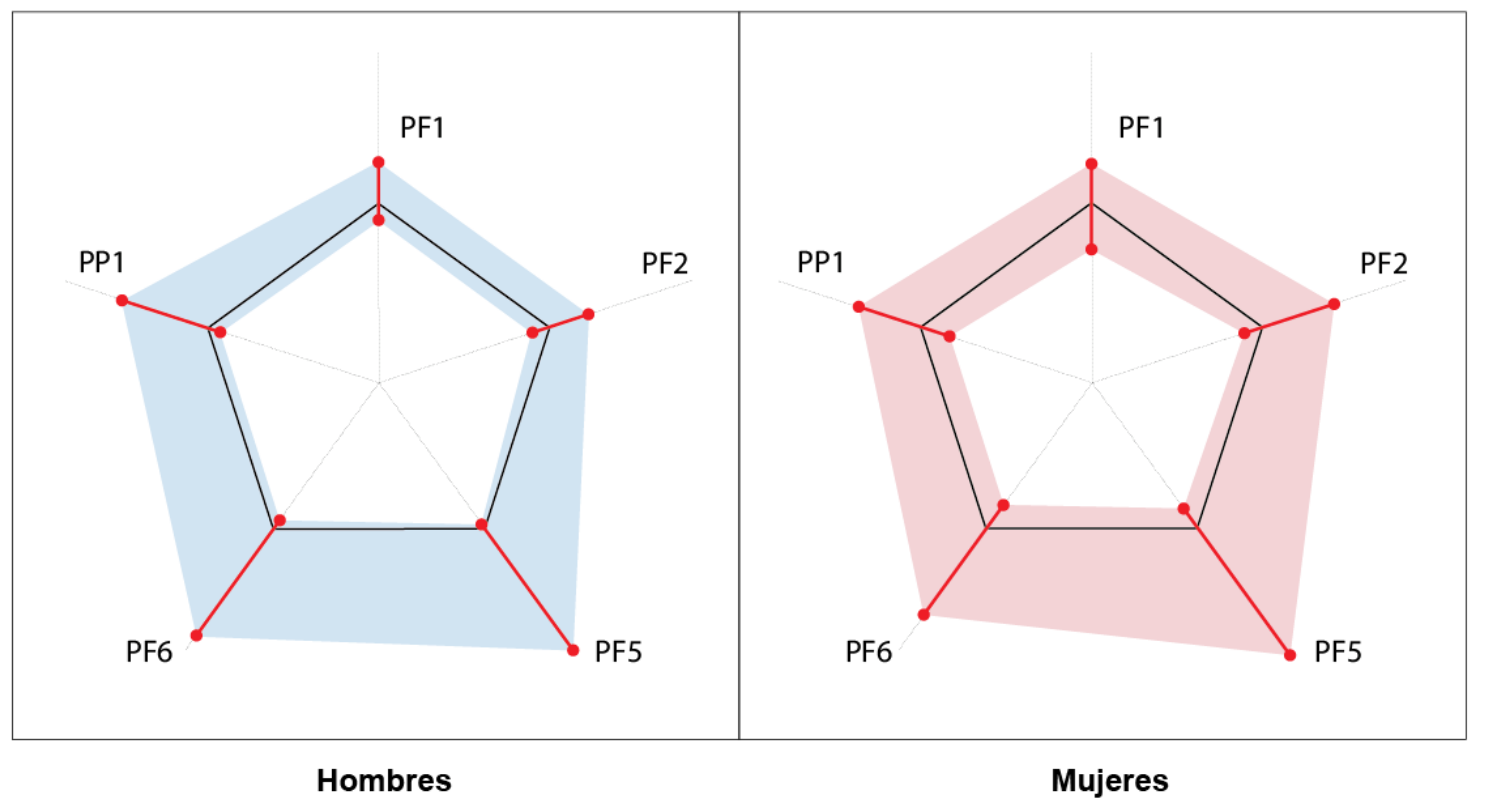

Tabla 49

\section{CONCLUSION.}

The concept of beauty is not a linear appreciation, but rather it is comprised within an interval where we can define a face as balanced and subdivide it in "normal", "good looking" and "very good looking".

Khosravanifard (2013)(28) published a study on how a backward jaw was linked to ugliness and how beauty was linked to slightly prominent noses, protruded upper lips, an inter-lip line located halfway between the chin and the nose and how straight side way profiles or with the chin slightly protruded made men more attractive.

Within a balanced face, there can be partial disproportions, which can constitute a harmonic whole if they are compensated with other elements of the face. Even if it is partially unbalanced, this face will be beautiful.

The cultural system in which the individual is immersed influences the beauty perception. Although we perceive unconsciously some liking when we notice faces where the Golden Ratio is present, it has also got to have a balanced composition.

In our study, a balanced face would be:

\section{MEN}

1. Balanced facial thirds

2. Normal nose or slightly narrow.

3. Eyes not sunken

4. Protruded lips

5. Straight side-way profile or chin Straight side-way profile or slightly back

\section{WOMEN}

Balanced or lower slightly diminished Narrow Nose

Big eyes and not sunken

Very protruded lips 
Slightly prominent.

This notion of aesthetics or balanced face has a narrow correlation with the Golden Ratio as we can see on table 54.

Among the proportions proposed by Ricketts we can restrict the study to 4 frontal ones:

1. PF1. Scalp-pupil to pupil-chin

2. PF2. Scalp-base of the nose to base of the nose-chin

3. PF5.Bi-pupil line-base of nose to base of nose-lip corner.

4. PF6. Base of nose-lip corner to lip corner-chin.

To these we should add another one referring to the side-view profile

5. PP1. Base of the ear-palpebral angle to palpebral angle-base of the nose. 


\section{ANNEX 1}

\section{LA ESTÉTICA FACIAL EN VISIÓN FRONTAL}

1. En conjunto, ¿cómo definiría a la persona de la fotografía?

Muy guapa, Guapa, Normal, Fea o Muy Fea

1. En conjunto, ¿diría usted que su rostro está armónico y equilibrado? En una escala de 10 a 0 ¿qué nota le otorgaría?

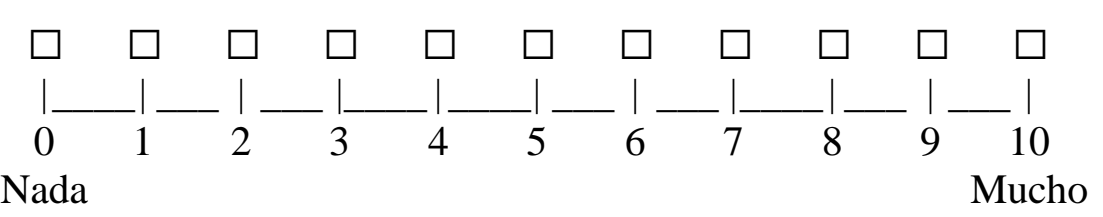

2. ¿Cómo aprecia usted la frente?

Muy grande, Grande, Normal, Pequeña o Muy pequeña

3. ¿Qué impresión le provocan las cejas? En cuanto a su anchura:

Muy anchas, Anchas, Normales, Estrechas o Muy estrechas

4. ¿Qué impresión le provocan las cejas? En cuanto a su separación

Muy separadas, Separadas, Normal, Juntas o Muy juntas

5. ¿Cómo aprecia los ojos?

Grandes, Normales o Pequeños

6. Tamaño de la nariz

Muy grande, Grande, Normal, Pequeña o Muy pequeña

7. Anchura de la nariz

Muy ancha, Ancha, Normal, Estrecha o Muy estrecha

8. El grosor de los labios le parece

Muy gruesos, Gruesos, Normales, Delgados o Muy delgados

9. Encuentra los labios

Muy protuidos, Protuidos, Normales, Hundidos o Muy hundidos

10. La sonrisa

Muy bonita, Bonita, Normal, Fea o Muy fea 
11. El mentón

Muy prominente, Prominente, Normal, Retraído o Muy retraído

12. La longitud de la cara le parece

Muy alargada, Alargada, Normal, Corta o Muy corta

13. La anchura de la cara le parece

Muy ancha, Ancha, Normal, Estrecha o Muy estrecha

14. Si divide el rostro en tres tercios: superior (frente), medio (nariz) e inferior (boca y mentón), ¿Qué tercio le parece más dominante?

Los tres tercios están equilibrados, Domina el tercio superior (frente), Domina el tercio medio (nariz) o Domina el tercio inferior (boca y mentón)

\section{LA ESTÉTICA FACIAL EN VISIÓN DE PERFIL}

15. Diría usted que la persona de la fotografía tiene un perfil

Muy bonito, Bonito, Normal, Feo o Muy feo

16. En una escala de 10 a 0 , donde 10 sería muy bella y 0 muy fea ¿cómo calificaría la belleza, equilibrio y armonía de este perfil?

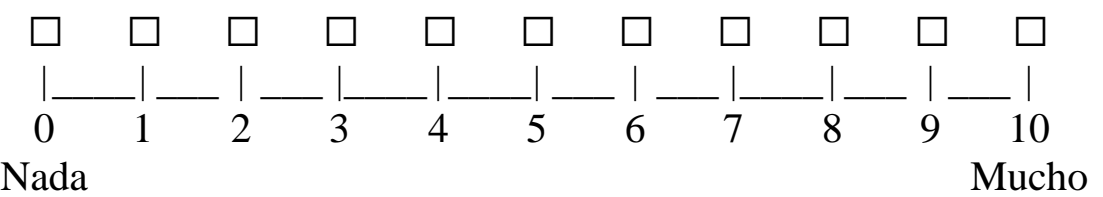

17. ¿Cómo aprecia usted la frente?

Muy grande, Grande, Normal, Pequeña o Muy pequeña

18. ¿Cómo percibe las cejas?

Muy grandes, Grandes, Normales, Pequeñas o Muy pequeñas

19. ¿Qué le parecen sus ojos?

Muy saltones Saltones, Normales, Hundidos, Muy hundidos

20. La nariz 
Muy grande, Grande, Normal, Pequeña o Muy pequeña

21. En una escala de 10 a 0 , donde 10 sería muy bonita y 0 muy fea ¿qué nota daría a la nariz?

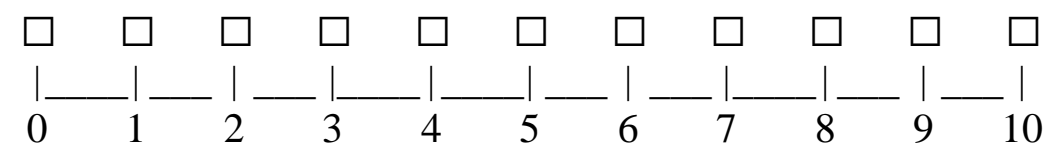

Muy fea

Muy bonita

22. Fíjese en el labio superior. Le parece

Muy carnoso, Carnoso, Normal, Fino o Muy fino

23. Le parece que el labio superior está

Muy protuido, Protuido, Normal, Hundido o Muy hundido

24. En una escala de 10 a 0 , donde 10 serían muy bonitos y 0 muy feos ¿qué nota daría a los labios?

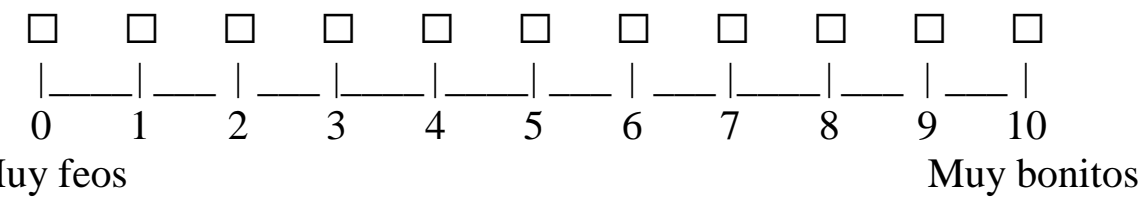

25. La sonrisa le parece

Muy bonita, Bonita, Normal, Fea o Muy fea

26. El mentón lo ve

Muy prominente, Prominente, Normal, Retraído o Muy retraído

27. ¿Qué impresión le da la longitud del perfil?

Cara muy alargada, Cara alargada, Cara normal, Cara corta o Cara muy corta

28. Le parece que tiene la cara

Cara muy hundida, Cara hundida, Cara normal, Cara prominente, Cara muy prominente 


\section{VALORACIONES SOBRE LA PERTINENCIA DE OPERAR}

29. Si usted fuese la persona de la fotografía ¿se operaría? Valore del 0 al 10, donde 0 significa seguro que no y 10 seguro que sí.

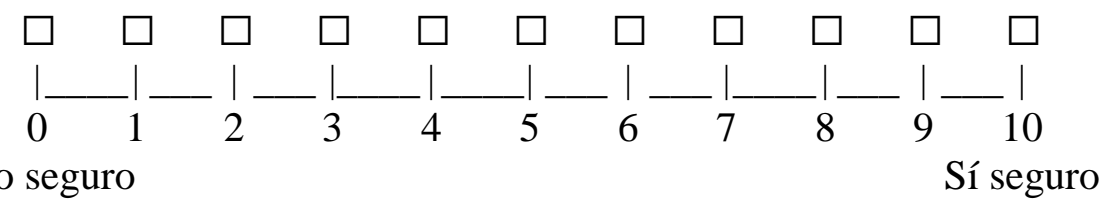

30. En el supuesto en que haya respondido 5 o más de 5 ¿Por qué se operaría?

Estar más guapo/a, Comer mejor, No perder dientes en un futuro

31. ¿Qué elementos tomaría en consideración a la hora de decidir operarse? Sí o No

Garantía de estar más guapo/a, Días de baja, Precio de la intervención, Riesgo de que salga mal, No creo que estar feo/a sea un motivo para operarse o Solo me operaría por motivos médicos

32. Mire la persona de la fotografía ¿Si fuese usted se operaría?

Sí o No

33. En el caso de haber respondido sí, ¿Qué parte del rostro le gustaría mejorar?

Tercio superior, Tercio medio o Tercio inferior 


\section{BIBLIOGRAFY.}

1. Farkas L.G., Katic M.J., Forrest C.R. et al. International anthropometric study of facial morphology in various ethnic groups/Races.

J. Craniofac Surg. 2005; 16:615-646.

2. Ricketts R.M. Divine proportion in facial esthetics.

Clin. Plast. Surg. 1982 Ovt; 9 (4): 401-22.

3. Preston J.D. The Golden Proportion Revisited. J. Esthet Dent. 1993; 5 (6): 247251.

4. Bashoure M. An objetive system for measuring facial attractiveness plast Reconstr. Surg. 2006; 118: 757-774.

5. Holland E. Marquardt's Phi mask: pit falls of relying on fashion models and the Golden ratio to describe a beautiful face. Aesthetic plast surg. 2008;32:200-208.

6. Duggal S, Kapoor DN, Verma S, Sagar M, Lee Y-S, Moon H, Rhee. S.C. Photogrammetic Analysis of attractiveness in indian faces. Arch plast surg. 2016 Mar; 43 (2): 160-171.

7. Murthy B.V., Ramani N. Evaluation of natural smile: Golden proportions, RED or Golden percentage. J. Conserv dent. 2008 Jan; 11(1): 16-21.

8. Pancherz $\mathrm{H}$, Knapp V, Erbe $\mathrm{C}$, Heiss AM. Divine proportions in attractive and non attractive face. World J Orthod. 2010 Spring: 11 (1): 27-36

9.Prokopakis EP, Vlastos JM, Picavet VA, Noist Trenite G, Thomas R, Cingi C, Helliges PW. The Golden ratio in facial symmetry. Rhinology 2013 Mar; 51 (1): 18-21.

10. Rajiv A, Juhi Y. Golden proportions as predictors of attracstiveness and malocclusion. Indian J Den Rev. 2014 Nov-Dic; 25 (6):788-793.

11. Shell TL, Woody MG. Facial aesthetics and the divine proportion; a comparison of surgical and non.surgical class II treatment. Aust Orthod J. 2004 Nov 20 (2):51-63.

12. Amoric M. The Golden number: applications to cranio-facial evaluation Funct Orthod 1995 Jan-Feb; 12 (1) :18-21, 24-25.

13. Baker BW, Woods MG. The role of the divine proportion in the esthetic improvement of patients undergoing combined orthodontic/orthognathic surgical treatment. Int J. Adult Orthodon Orthognath surg. 2001; 16 (2): 108-120.

14. Jahanbin A, Basafa M, Alizadeh $Y$. Evaluation of the divine proportion in the facial profile of Young females. Indian J Dent Res 2008 Oct-Dec; 19(4): 292-296. 
15. Mahshid M, Khoshvaghti A, Varshosaz M, Vallael N. Evaluation of "Golden proportion" in individuals with an esthetic smile. J. Esthet Restor Dent. 2004; 16(3): 183-193; discussion 193.

16. Medici Filho E, Martins MV, Dos Santos Da Silva MA, Castilho J.C. De Moraes LC, Gil CT. Divine proportions and facial esthetic after manipulation of frontal photographs. World J. Orthod 2007 Summer, 8 (2): 103-108.

17. Zhao Q, Zhou R, Zhang X, Sun H, Lu X, Xia D, Song M, Liang Y. Morphological quantitative criteria and aesthetic evaluation of eight female han face types. Aesthetic plast Surg. 2013 Apr; 37 (2) :445-453.

18. Hönn M, Göz G. The ideal of facial beauty: a review. J. Orofac Orthop 2007 Jan; 68 (1): 6-16.

19. Knight H, Keith O. Ranking facial attractiveness. Eur J. Orthod 2005 Aug; 27 (4) 340-348.

20. Perrett D., May Ka, Yoshikawa S. Facial shape and judgements of female attractiveness. Nature. 1-994 Mar. 17; 368 (6468) 239-242.

21. Macías Gago AB, Romero Manoto $M$, Crego A. The perception of funcional aesthetics in a Young spanish population. Eur J. Orthod. 2012 Jun; 34 (3): 335339.

22. Aníc-Milosëvíc S, Lapter-Vargha M, Dumancic J, Slaj M.

Analisis of the soft tissue profile in Croatians with normal oclusions and wellbalanced face. Eur. J. Orthod 2011 Jun; 33 (3): 305-310.

23. Jefferson Y. Facial esthetics-presentation of an ideal face. J. Gen Orthod 1993 Mar; 4 (1) : 18-23.

24. Yu XN, Bai D, Feng X, Lin YH, Chen WJ. Correlation beween cephalometric measures and End- of - treatment facial attractiveness . J Cranio Fac Surg, 2016 Mar; 27 (2) :405-409.

25. Johnston DJ, Hunt O, Johnston (1), Burden DJ, Stevensson M, Hepper P. The influence of lower face vertical proportion on facial attractiveness. Eur $\mathrm{J}$ Orthod 2005 Aug; 27 (4): 349-354.

26. Devcic Z, Rayikanti BA, Hevia JP, Popenki NA, Karimik, Wong B.J. Nasal tip projection and facial attractiveness. Laryngoscope. 2011 Jul; 121(7):1388-1394.

27. Soler C, Kekäläimen J, Númez M, Sancho M, Núñez J, Yaber I, Gutiérrez R,. Male facial anthropometry and Attractriveness. Perception 2012; 41 (20): 12341245.

28. Khosravanifard B. Ralkhshan V, Raeesi E. Factors influencing attractiveness of soft tissue profile. Oral Surg. Oral Med Oral Pathol Oral RAdiol . 2013 Jan; 115 (1):29-37. 
29. Rossetti A., De Menezes M, Rosati R, Ferrario VF S, Forza C. The role of the Golden proportion in the evaluation of facial esthetics. Angle Orthod, 2013 Sep; 83 (5):801-808.

30. Modarai F, Donaldson JC, Naini FB. The influence of lower lip position on the perceived atractiveness of chin prominence angle orthod $2013 \mathrm{sep}, 83$ (5): 795 800.

31. Scheideman GB, Bell WH, Legan HL, Finn RA, Reisch JS. Cephalometric analysis of dentofacial normals. Am J. Orthod. 1980 Oct; 78 (4): 404-420.

32. Erbay EF, Canikliogln C.M. Soft tissue profile in Anatolian Turkish adults; Part II. Comparison of different soft tissue analyses in the evluation of beauty.

34. Nomura M, Motegi E, Hatch JP, GAkunga PT, Ngángá PM, Rugh JD, Yamaguchi $\mathrm{H}$. Esthetic preferencies of European American, Hispanic american, Japanese, and African Judges for soft tissue profiles. Am J. Orthod Dentofacial orthop. 2009 Apr; 135 (4 suppl); S 87-95.

35. Michiels G, Sather Ah. Determinants of facial attractiveness in a simple of White women. Int. J. Adult Orthodon. Orthognath Surg 1994; 9 (2): 95-103.

36. Mesaros A, Cornea D, Cioara L, Dudea D, Mesaros M, Badea M. Facial attractiveness assessment using illustrated questionnairer. Clujul Med. 2015; 88(1):73-78. 